\title{
Long-term responses of Scots pine (Pinus sylvestris L.) and European beech (Fagus sylvatica L.) to the contamination of light soils with diesel oil
}

\author{
Agnieszka Bęś ${ }^{1}$ (D) Kazimierz Warmiński ${ }^{1}$ Barbara Adomas ${ }^{1}$
}

Received: 23 October 2018 / Accepted: 22 January 2019 /Published online: 14 February 2019

(C) The Author(s) 2019

\begin{abstract}
Research into trees plays a very important role in evaluations of soil contamination with diesel oil. Trees are ideal for reclaiming contaminated soils because their large biomass renders them more resistant to higher concentrations of pollutants. In the literature, there is a general scarcity of long-term studies performed on trees, in particular European beeches. The aim of this study was to evaluate the responses of Scots pines and European beeches grown for 8 years on soil contaminated with diesel oil. Selected morphological and physiological parameters of trees were analyzed. The biomass yield of Scots pines was not significantly correlated with increasing concentrations of diesel oil, but it was more than $700 \%$ higher than in European beeches. Scots pines were taller and had a larger stem diameter than European beeches during the 8-year study. The diameter of trees grown on the most contaminated soil was reduced 1.5-fold in Scots pines and more than twofold in European beeches. The length of Scots pine needles from the most contaminated treatment decreased by $50 \%$ relative to control needles. The shortest needles were heaviest. The fluctuating asymmetry (FA) of needle length was highest in Scots pines grown on the most contaminated soil, whereas the reverse was noted in the FA of needle weight. Diesel oil decreased the concentrations of chlorophylls $a$ and $b$, total chlorophyll, and carotenoids. The Fv/Fm ratio of needles and leaves was influenced by the tested concentrations of diesel oil. The results of the study indicate that the Scots pine better adapts (grows more rapidly and produces higher biomass) to long-term soil contamination with diesel oil than the European beech. In European beeches, growth inhibition and leaf discoloration (a decrease in chlorophyll content) were observed already after the first year of the experiment, which indicates that 1-year-old seedlings of European beech are robust bioindicators of soil contamination with diesel oil.
\end{abstract}

Keywords Soil · Diesel oil $\cdot$ Scots pine $\cdot$ European beech $\cdot$ Morphological parameters $\cdot$ Chlorophyll fluorescence

\section{Introduction}

Environmental pollution with crude oil and petroleum derivatives is a widespread problem around the world. It is caused by oil rig and oil tanker disasters as well as the extraction, land transport, processing, and storage of fuels. The ecological consequences of petroleum contamination are observed in

Responsible editor: Zhihong Xu

Agnieszka Bęś

agnieszka.bes@uwm.edu.pl

1 Department of Chemistry, Research Group of Environmental Toxicology, Faculty of Environmental Management and Agriculture, University of Warmia and Mazury in Olsztyn, ul. Prawocheńskiego 17, 10-720 Olsztyn, Poland plants, animals, and humans in all ecosystems (Howarth 1989; Singer et al. 1990; Singh et al. 2004; Tamada et al. 2012; Klamerus-Iwan et al. 2015; Sagerup et al. 2016).

Petroleum substances are produced during the distillation of various crude oil fractions. These fractions can be divided into four main categories: light distillates (liquefied petroleum gas, gasoline, naphtha), middle distillates (naphtha, diesel oil), heavy distillates (heavy fuel oil, lubricating oils, paraffin wax), and remaining fractions (asphalt) (Mackerer et al. 2003). The global demand for petroleum continues to grow, and it increased to 95.0 million barrels per day between 2015 and 2016 (International Energy Agency 2016). Diesel oil is widely used in transportation. In 2016, the demand for diesel was highest in Europe and the USA and was considerably lower in Asia and Oceania at 4.70, 4.56, and 1.30 million barrels, respectively. According to World Oil Outlook 2011, the global demand for diesel oil will reach 11.3 million barrels 
per day in 2035. The predicted increase in demand has highly adverse implications for the natural environment. Diesel oil combines several petroleum fractions (paraffins, naphthenes, olefins, and aromatic hydrocarbons), and its chemical structure is responsible for its toxicity (Domínguez-Barroso et al. 2016). The toxicity of diesel oil is also determined by dose, time of exposure, and the exposed organism (Bona et al. 2011). The mean mortality rate of the freshwater crustacean Daphnia magna exposed to diesel oil has been determined at $78.34 \%$ and acute toxicity (LC50)-at $1.78 \mathrm{ppm}$. Onchorynchus mykiss is a more resistant organism, and its mortality rate under exposure to the lowest concentration of diesel oil (100 ppm) was determined at $38.33 \%$, mean mortality after $96 \mathrm{~h}$ of exposure - at $70.71 \%$, and acute toxicity (LC50) - at $133.52 \mathrm{ppm}$ (Khan et al. 2007).

Soils are reclaimed with the use of higher plants, including selected varieties of poplars (Populus spp.), willows (Salix spp.), birches (Betula neoalaskana), white spruces (Picea glauca), balsam poplars (Populus balsamifera), and Enterolobium contortisiliquum which are characterized by high biomass and considerable resistance to high doses of polluting substances (Garbisu et al. 2002; Leewis et al. 2013). These plants should not only accumulate and degrade contaminants, but they should also be able to grow in degraded habitats. Trees are ideal for reclaiming contaminated soils because their large biomass renders them more resistant to higher concentrations of pollutants. Trees have extensive root systems which are capable of accumulating large quantities of polluting substances. Phytoremediation is a non-invasive, environmentally friendly, and cost-effective alternative to physical remediation methods. However, research into phytoremediation is still in its early stages and requires further long-term studies (Kamath et al. 2004).

Tree health is influenced by both biotic and abiotic stressors (Schaberg et al. 2008). The responses of trees to drought have been widely studied under both controlled and field conditions (Löf et al. 2005; Chakraborty et al. 2017; Gazol et al. 2018). The effect of soil contamination with heavy metals on plant biomass has also been extensively described in the literature (Derome and Saarsalmi 1999; Stefanowicz et al. 2016; Grobelak et al. 2017; Pająk et al. 2017). In contrast, there is a general scarcity of research into tree responses to soil contamination with petroleum derivatives (Leewis et al. 2013; Villacís et al. 2016).

Xenobiotics present in the soil environment inhibit plant metabolic processes such as the activity of oxidative enzymes (Hussain et al. 2018) and biogenic amines (Baciak et al. 2017); they disrupt photosynthesis and fluorescence emission (Sousa et al. 2014). Photosynthetic efficiency and biomass yield can be compromised even when the damage to the photosynthetic apparatus is not yet visible.

Diesel oil modifies the morphological and biochemical parameters of plants growing on contaminated soil.
However, the responses of Scots pines and European beeches grown for 8 years on contaminated soil have never been investigated. There are no studies analyzing the influence of diesel oil on beeches, either. For this reason, this study was undertaken to describe the effects of diesel oil on Scots pines and European beeches and to determine which of the analyzed tree species is a better bioindicator of soil contamination with diesel oil and is capable of rapidly adapting to degraded habitats and producing large amounts of biomass.

The aim of this study was to evaluate selected morphological and physiological parameters of Scots pines and European beeches grown for 8 years on soil contaminated with diesel oil.

\section{Materials and methods}

\section{Pot experiment}

The experiment was conducted for 8 years (2009-2016) in the Experimental Station of the University of Warmia and Mazury in Olsztyn, Poland. Five 1-year-old seedlings of Scots pine and European beech were planted per pot. Each pot was filled with $14 \mathrm{~kg}$ of light soil contaminated with the following amounts of diesel oil (LOTOS Eurodiesel): 0, 3, 6, 12, and $24 \mathrm{~g}$ of diesel oil per $1 \mathrm{~g}$ of soil dry matter (Table 1). Soil moisture content was maintained at $75 \%$ field water capacity throughout the experiment. Soil moisture was monitored with the $\mathrm{FOM} / \mathrm{mts}$ time-domain reflectometer (Institute of Agrophysics of the Polish Academy of Sciences, Lublin, Poland). The experiment was carried out in five replications ( $\sum=50$ pots). The pots were maintained under natural conditions.

Table 1 Selected chemical and physical properties of the study soil

\begin{tabular}{ll}
\hline Parameter & Measured value \\
\hline $\mathrm{pH}_{\mathrm{KCl}}$ & 7.11 \\
$\mathrm{pH}_{\mathrm{H} 2 \mathrm{O}}$ & 7.72 \\
$\mathrm{P}_{2} \mathrm{O}_{5}(\mathrm{mg} / \mathrm{kg}$ soil) & 501.0 \\
$\mathrm{~K}_{2} \mathrm{O}(\mathrm{mg} / \mathrm{kg}$ soil) & 175.0 \\
$\mathrm{Mg}(\mathrm{mg} / \mathrm{kg}$ soil) & 42.0 \\
$\mathrm{C}(\%)$ & 1.84 \\
$\mathrm{~N}$ total $(\%)$ & 0.141 \\
$\mathrm{Hydrolytic} \mathrm{acidity} \mathrm{(me/kg} \mathrm{soil)}$ & 7.6 \\
$\mathrm{Granulometric} \mathrm{composition} \mathrm{( \%} \mathrm{fraction} \mathrm{content)}$ & \\
$2-0.05 \mathrm{~mm}$ & 72.21 \\
$0.05-0.02 \mathrm{~mm}$ & 15.13 \\
$0.02-0.002 \mathrm{~mm}$ & 11.30 \\
$<0.002 \mathrm{~mm}$ & 1.36 \\
\hline
\end{tabular}




\section{Biometric parameters}

Plant height was measured from the base of the stem to the tip of the main shoot after planting and in autumn of each year. Stem diameter was measured $1 \mathrm{~cm}$ above soil surface in the last year of the experiment. Ten pairs of 2-year-old needles were collected from every Scots pine before harvest. The length of each needle in the pair was measured to the nearest $\pm 1 \mu \mathrm{m}$ by digital image analysis in the Image Tool 3.0 program (UTHSCSA, USA). The needles were dried to constant weight at a temperature of $60^{\circ} \mathrm{C}$ for $48 \mathrm{~h}$, and each needle in the pair was weighed separately.

\section{Fluctuating asymmetry of Scots pine needles}

The developmental stability of Scots pine needles was determined based on fluctuating asymmetry (FA) as the difference in length in each needle pair, divided by the length of the longer needle. Two FA indicators were determined based on needle length (FAL) and needle weight (FAW) according to the following formulas (Kozlov et al. 2002):

$$
\begin{aligned}
\mathrm{FAL} & =\frac{(L 1-L 2)}{0.5(L 1+L 2)} \\
\mathrm{FAM} & =\frac{(W 1-W 2)}{0.5(W 1+W 2)}
\end{aligned}
$$

\section{$L 1, L 2 \quad$ needle length}

$W 1, W 2$ needle weight

\section{Chlorophyll content and phaeophytization quotient}

The chlorophyll content of leaves and needles was determined spectrophotometrically in the first year of the experiment after xenobiotic application and in the last year of the experiment before biomass harvest. Plant material for analyses was prepared according to the procedure described by (Barnes et al. 1992). Ten leaves/needles were sampled from each plant. Each test tube was filled with $40 \mathrm{mg}$ of ground leaves/ needles and $4 \mathrm{~cm}^{3}$ of dimethyl sulfoxide (DMSO) for spectroscopy (Uvasol ${ }^{\circledR}$, Merck, Germany). Test tubes were placed in a water bath with a temperature of $60^{\circ} \mathrm{C}$ and extracted for $3 \mathrm{~h}$ in darkness. The solution was cooled to room temperature; $2 \mathrm{~cm}^{3}$ of the extract was diluted 1:1 with DMSO and allowed to cool to ambient temperature before diluting 1:1 with fresh DMSO. The absorbance spectrum (400 to $800 \mathrm{~nm}$ ) was measured, and absorbance peaks were determined at 750.0, 648.0, $665.0,480.0,435.0$, and $415.0 \mathrm{~nm}$ with the Hitachi U-1800 spectrophotometer (Tokyo, Japan). The concentrations of chlorophylls $a$ and $b$, carotenoid content, and the phaeophytization quotient were calculated according to the following formulas (Chai et al. 2018):

$$
\begin{aligned}
& \text { Chla }=C_{\text {Chla }} \cdot \frac{V_{\mathrm{e}} \cdot x}{m} \\
& \text { Chlb }=C_{\text {Chlb }} \cdot \frac{V_{\mathrm{e}} \cdot x}{m}
\end{aligned}
$$

where

Chla, Chlb chlorophyll concentration in plant material $\left[\mu \mathrm{g} \cdot \mathrm{mg}^{-1}\right]$ $V_{\mathrm{e}} \quad$ volume of DMSO extract $\left(V_{\mathrm{e}}=4 \mathrm{ml}\right)$

$x \quad$ dilution coefficient

$m \quad$ sample weight [mg]

$$
C_{\text {Chla }}=12.47 \cdot A_{665}-3.62 \cdot A_{648}
$$$$
C_{\text {Chlb }}=25.06 \cdot A_{648}-6.5 \cdot A_{665}
$$

where

$C_{\text {Chla }} \quad$ concentration of chlorophyll $a$ in the extract $\left[\mu \mathrm{g} \cdot \mathrm{ml}^{-1}\right]$ $C_{\mathrm{Chlb}} \quad$ concentration of chlorophyll $b$ in the extract $\left[\mu \mathrm{g} \cdot \mathrm{ml}^{-1}\right]$ $A_{i} \quad$ solution absorbance at $i$ th wavelength

$\mathrm{TCC}=\frac{\left[1000 \cdot A_{480}-(1.29 \cdot \mathrm{Chla})-(53.78 \cdot \mathrm{Chlb})\right]}{220}$

where

$\begin{array}{ll}\text { TCC } & \text { total carotenoid content } \\ \text { Chla, Chlb } & \text { chlorophyll content in plant material }\left[\mu \mathrm{g} \cdot \mathrm{mg}^{-1}\right] \\ A_{i} & \text { solution absorbance at } i \text { th wavelength }\end{array}$

The results were expressed in milligrams of chlorophyll per gram of leaf fresh matter.

$\mathrm{PQ}=\frac{A_{435}}{A_{415}}$

where

PQ phaeophytization quotient

$A_{435}, A_{415}$ solution absorbance at a given wavelength [nm]

\section{Greenness index of European beech leaves}

The greenness index was determined in ten leaves from each plant with the use of the SPAD 502 chlorophyll meter (Konica Minolta, Japan). The measurements were performed only for European beech leaves due to morphological differences between the analyzed plants. The greenness index was expressed in unitless SPAD values.

\section{Chlorophyll $a$ fluorescence}

The maximum quantum yield of PSII ( Fv/Fm) was measured in the needles/leaves growing in the top half of a new shoot (5 plants per pot, 2 measurements per plant) with the HandyPEA chlorophyll fluorescence system (Hansatech Instruments Ltd., 
UK). The measurements were repeated on the same plants throughout the experiment. The Fv/Fm ratio was calculated each year in August and at harvest. Leaves/needles were covered with clips for $30 \mathrm{~min}$ to inhibit the light dependent phase of photosynthesis. Fluorescence kinetics was induced on an area of $4 \mathrm{~mm}$ with light intensity of $3000 \mu \mathrm{mol} \mathrm{m}^{-2} \mathrm{~s}^{-1}$. Maximum fluorescence $\left(\mathrm{F}_{\mathrm{M}}\right)$ was measured for $100 \mu \mathrm{s}$. Kinematic data were analyzed in the Pocket PEA Plus V1.10 program (Hansatech Instruments Ltd.).

\section{Statistical analysis}

The normal distribution of parameters in each independent group was determined by the Shapiro-Wilk test, and the residuals were also tested for normality. The homogeneity of variance was confirmed in Levene's test. Factorial ANOVA ( $F$ test) was performed. The experimental factors were as follows: tree species, diesel oil dose, and year of study. Significant differences were determined in Tukey's test at $p<0.05$. Two-factor and three-factor analyses of variance and a regression analysis were carried out. The results of the experiment, including biomass yield, tree height, stem diameter, chlorophyll $a$ and chlorophyll $b$ content, chlorophyll $a$ fluorescence, leaf greenness index (SPAD), and fluctuating asymmetry indicators, were processed in the Statistica 11.0 program (StatSoft Inc. 2017).

\section{Results}

\section{Biometric parameters and biomass yield}

Diesel oil significant differentiated the biometric parameters of trees (Table 2). Scots pines were approximately 50\% taller than European beeches. The tallest Scots pines and European beeches grew on control soil, whereas the shortest trees grew on soil contaminated with the highest dose of diesel oil (Fig. 1). The height of control trees and trees growing on contaminated soil increased by more than $74 \%$ during the 8 year experiment (Fig. 1).

In soil contaminated with diesel oil (12 and $24 \mathrm{~g} / \mathrm{kg}$ soil $\mathrm{DM})$, the growth of Scots pines was inhibited in the third year of the experiment. In contrast, the growth of European beeches on soil with the lowest dose of diesel oil was inhibited already in the first year. During the entire experiment, the height of Scots pines increased by $474 \%$ in the control treatment and by $322-442 \%$ in contaminated treatments. The height of European beeches increased by $405 \%$ in the control treatment and by only $271 \%$ in the most contaminated treatment (Fig. 2). The height of both tree species was significantly correlated with the experimental year. The quadratic function best fit the experimental data, and the value of $R^{2}$ exceeded 0.98 . All modeled parameters were statistically significant for the height of European beeches, and most parameters were statistically significant for the height of Scots pines $(p>0.05)$ (Fig. 2). A multiple regression analysis revealed that tree height was also influenced by diesel oil dose and year of study. The experimental data were best described by the modeled height of Scots pines, where $R^{2}$ was determined at 0.92 and standard error of estimation - at 7.6 (Fig. 3).

Scots pine needles from the control treatment were longest at $61.8 \mathrm{~mm}$ on average, whereas the needles from treatments contaminated with the highest doses of diesel oil were twice shorter. Needle weight increased with diesel oil dose. The heaviest needles $(6.12 \mathrm{~mm})$ were collected from the treatment with the highest diesel oil dose $(24 \mathrm{~g} / \mathrm{kg}$ soil DM), and they were $66.77 \%$ heavier than control needles. Needle thickness also increased with the degree of contamination (Fig. 4). The needles from the most contaminated treatment were 3.3-fold thicker than control needles.

Scots pines and European beeches growing on soil with the highest concentration of diesel oil were characterized by the smallest stem diameters (Fig. 5). The average stem diameter was nearly twice larger in Scots pines than in European beeches at 15.9 and $8.4 \mathrm{~cm}$, respectively.
Table 2 Analysis of variance $(F$ test) of height of trees (Scots pine and European beech)

\begin{tabular}{llllll}
\hline Source of variation & Sum of squares & df & Mean square & $F$ & $p$ value \\
\hline Intercept & $1,074,323$ & 1 & $1,074,323$ & $22,853.15$ & $<0.001$ \\
$\mathrm{~S}$ & 115,872 & 1 & 115,872 & $2464.85^{* *}$ & $<0.001$ \\
$\mathrm{O}$ & 23,613 & 4 & 5903 & $125.57^{* *}$ & $<0.001$ \\
$\mathrm{Y}$ & 116,246 & 7 & 16,607 & $353.26^{* *}$ & $<0.001$ \\
$\mathrm{~S} \times \mathrm{O}$ & 345 & 4 & 86 & $1.83 \mathrm{n} . \mathrm{s}$. & 0.122 \\
$\mathrm{~S} \times \mathrm{Y}$ & 47,988 & 7 & 6855 & $145.83^{* *}$ & $<0.001$ \\
$\mathrm{O} \times \mathrm{Y}$ & 4370 & 28 & 156 & $3.32^{* *}$ & $<0.001$ \\
$\mathrm{~S} \times \mathrm{O} \times \mathrm{Y}$ & 1575 & 28 & 56 & 1.20 n.s. & 0.232 \\
Error & 13,727 & 292 & 47 & & \\
\hline
\end{tabular}

$S$, species; $O$, diesel oil dose; $Y$, year; $S \times O, S \times Y, O \times Y, S \times O \times Y$, interactions between the factors

*Significant at $p<0.05 ; *$ significant at $p<0.01 ; n s$ not significant 


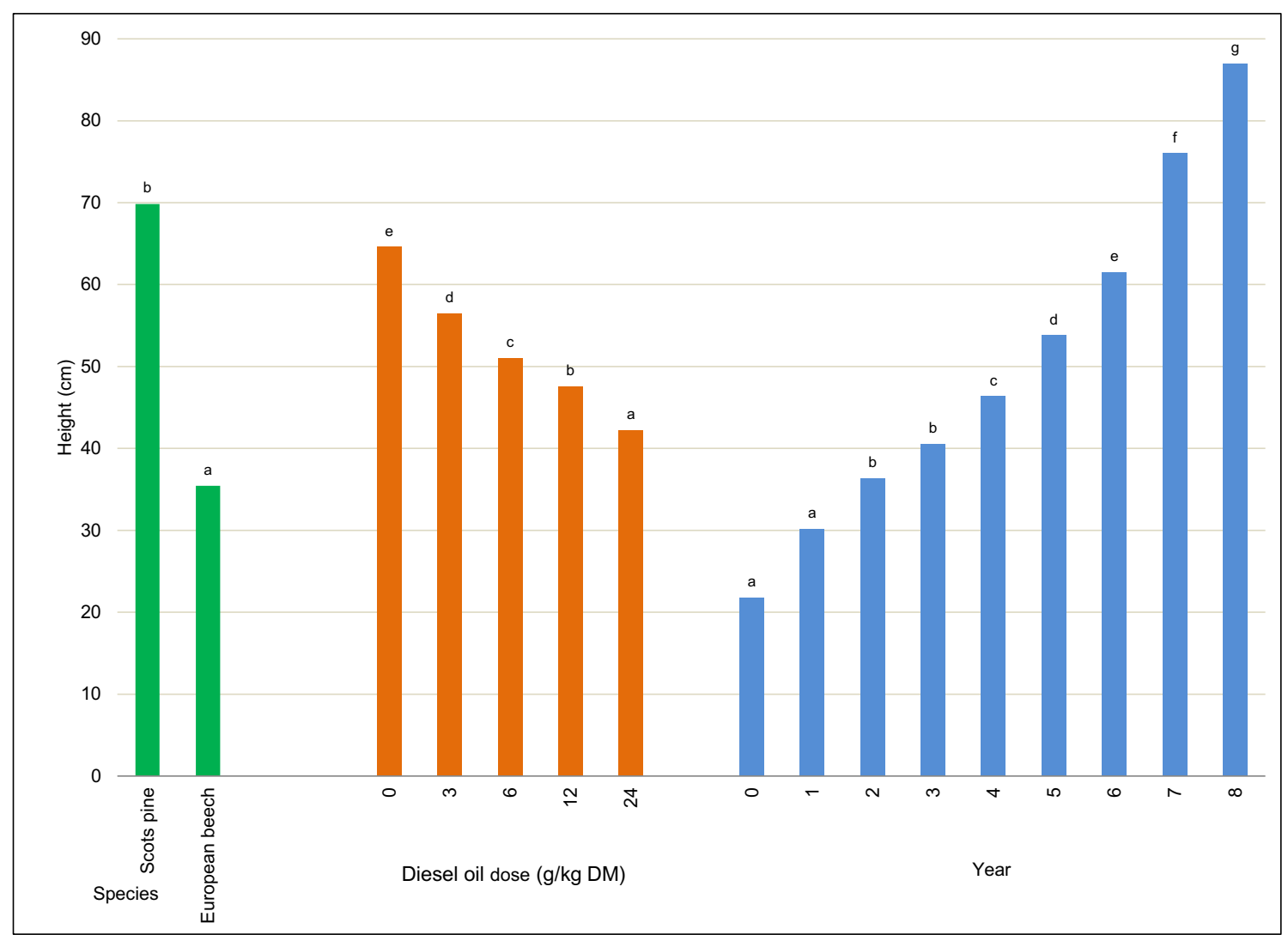

Fig. 1 Average height depending on the tree species, the diesel oil dose, and the year of experiment. Different letters above the columns indicated significant difference at the $p<0.05$

Unlike in European beeches, the biomass yield of Scots pines was not significantly affected by diesel oil. The biomass yield of European beeches was significantly lower in all contaminated treatments. The analyzed parameter decreased by $83 \%$ in the most contaminated treatment, and it decreased by $35 \%, 37 \%$, and $62 \%$ in treatments containing 3, 6 , and $12 \mathrm{~g}$ of diesel oil $/ \mathrm{kg}$ of soil DM, respectively (Fig. 6).

\section{Fluctuating asymmetry}

In the last year of the experiment, fluctuating asymmetry indicators were determined in Scots pine needles before biomass harvest. The analyzed parameters were significantly differentiated by the applied dose of diesel oil (Table 3). The FAL was lowest in the control treatment (0.01). Similar FAL values were noted in Scots pine needles from treatments
Fig. 2 Temporary trends in the height of Scots pine (a) and European beech (b) depending on the diesel oil dose
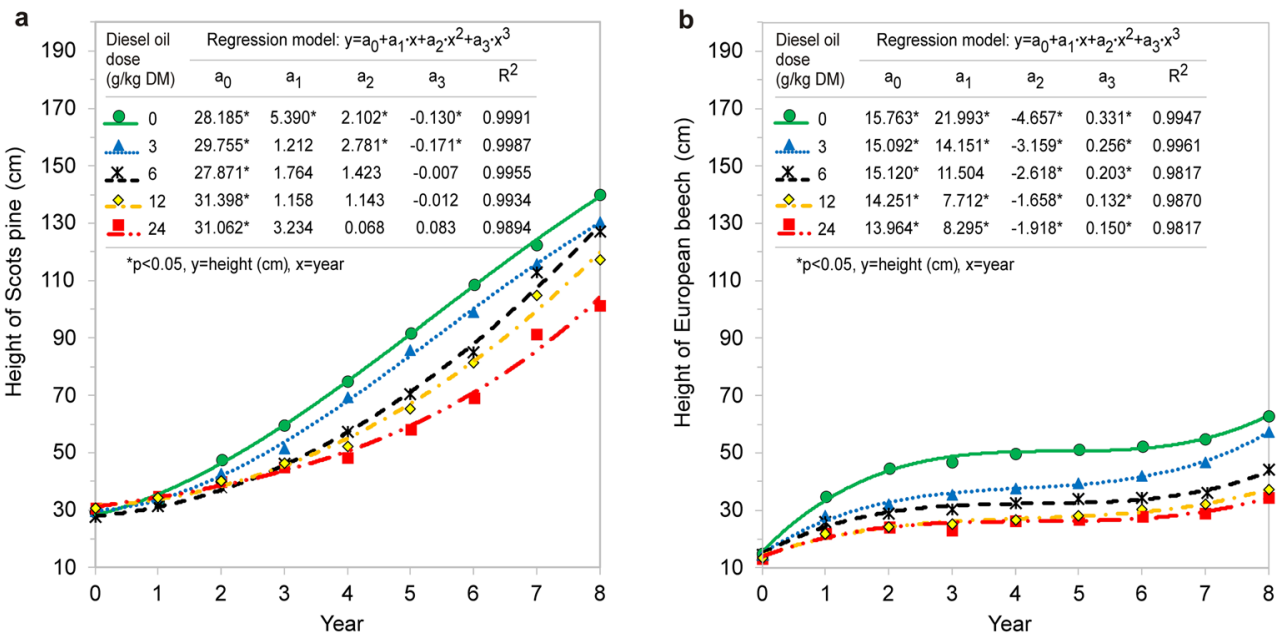
Fig. 3 Relationship between the height of trees (a Scots pine, b European beech) and the diesel oil dose and the year of study. SEE is a standard error of estimation a

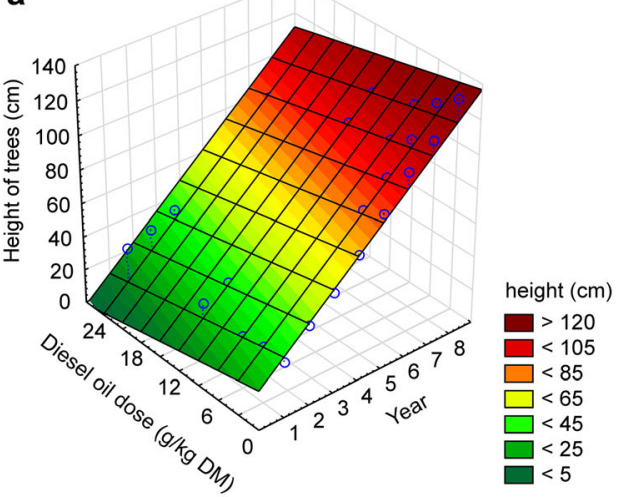

Regression model: $z=b_{0}+b_{1} \cdot x+b_{2} \cdot y$

Estimated parameters: $b_{0}=23.3886, b_{1}=12.6081, b_{2}=-0.9257, R^{2}=0.9248$ ANOVA: $F=310.4, p=7.5 \cdot 10^{-24}, S E E=7.6$ b

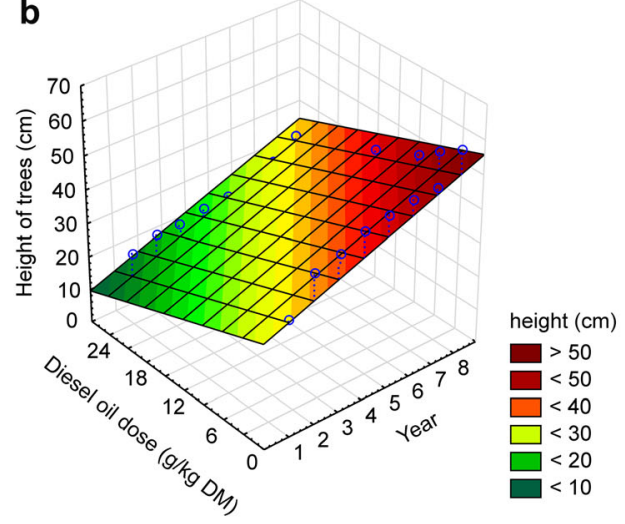

Regression model: $z=b_{0}+b_{1} \cdot x+b_{2} \cdot y$

Estimated parameters: $b_{0}=30.9983, b_{1}=2.7619, b_{2}=-0.7924, R^{2}=0.7999$ ANOVA: $F=73.9, p=1.2 \cdot 10^{-13}, \mathrm{SEE}=4.8$ contaminated with 3 and $6 \mathrm{~g}$ of diesel oil/ $\mathrm{kg}$ of soil DM. The FAL increased significantly with contamination level and was determined at 0.10 and 0.18 , respectively (Fig. 7).

A reverse relationship was observed in the values of FAW. The FAW was highest in the control treatment and in the treatment contaminated with $3 \mathrm{~g}$ of diesel oil $/ \mathrm{kg}$ of soil DM (0.19 and 0.21 , respectively), and it was lowest in treatments with higher doses of diesel oil (0.11 to 0.14) (Fig. 7).

\section{Chlorophyll content, phaeophytization quotient, and leaf greenness index}

\section{Chlorophyll content}

In the first year of the study, the content of chlorophylls $a$ and $b$ and carotenoids in Scots pine needles was not differentiated by the tested doses of diesel oil. In the last year of the study, the concentrations of chlorophylls $a$ and $b$ in Scots pine needles decreased with a rise in diesel oil dose. In needles collected from the most contaminated treatment, the content of chlorophylls $a$ and $b$ decreased by $50 \%$. Total chlorophyll content was lowest (1.16) in needles from the treatment contaminated with $24 \mathrm{~g}$ of diesel oil $/ \mathrm{kg}$ of soil DM. In the control treatment, the above parameter was determined at 2.30 . Only minor differences in the carotenoid content of needles were observed between treatments (Fig. 8).

In comparison with Scots pine needles, the content of chlorophyll $a$ in European beech leaves was higher both in the first and the last year of the experiment. The above parameter decreased significantly with a rise in diesel oil dose. In the last year of the study, the lowest concentration of chlorophyll $a$ was noted in leaves from treatments contaminated with 12 and $24 \mathrm{~g}$ of diesel oil/ $\mathrm{kg}$ of soil DM at 1.84 and $1.62 \mathrm{mg} / \mathrm{g}$, respectively. The carotenoid content of European beech leaves was similar to that observed in Scots pine needles (Fig. 8).

\section{Phaeophytization quotient}

The phaeophytization quotient (PQ) was significantly correlated with the applied dose of diesel oil only in European beech leaves. Control leaves were characterized by higher PQ values than leaves from the most contaminated treatment (0.91 and 0.58, respectively) (Fig. 8).

\section{Leaf greenness index}

The greenness index of European beech leaves differed significantly between the first and last year of the study and was correlated with soil contamination levels (Fig. 9, Table 4). In the first year of the experiment, the highest SPAD value was noted in control leaves (20.04). The SPAD value of European beech leaves from the most contaminated treatment was $27.0 \%$ lower on average (14.61). A similar trend was noted during the second measurement in the last year of the study.

\section{Chlorophyll fluorescence}

The Fv/Fm ratio of Scots pines growing in all contaminated treatments decreased significantly in the first 4 years of the experiment relative to control. Beginning from year 5 , the above parameter increased significantly relative to the first 4 years. The Fv/Fm ratio of control trees ranged from 0.75 to 0.79 , and the Fv/Fm ratio of trees grown on the most contaminated soil ranged from 0.57 (in 3 years and 4 years) to 0.71 (in 6 years and 7 years) (Fig. 10). A different trend was observed in European beeches, where the Fv/Fm ratio 

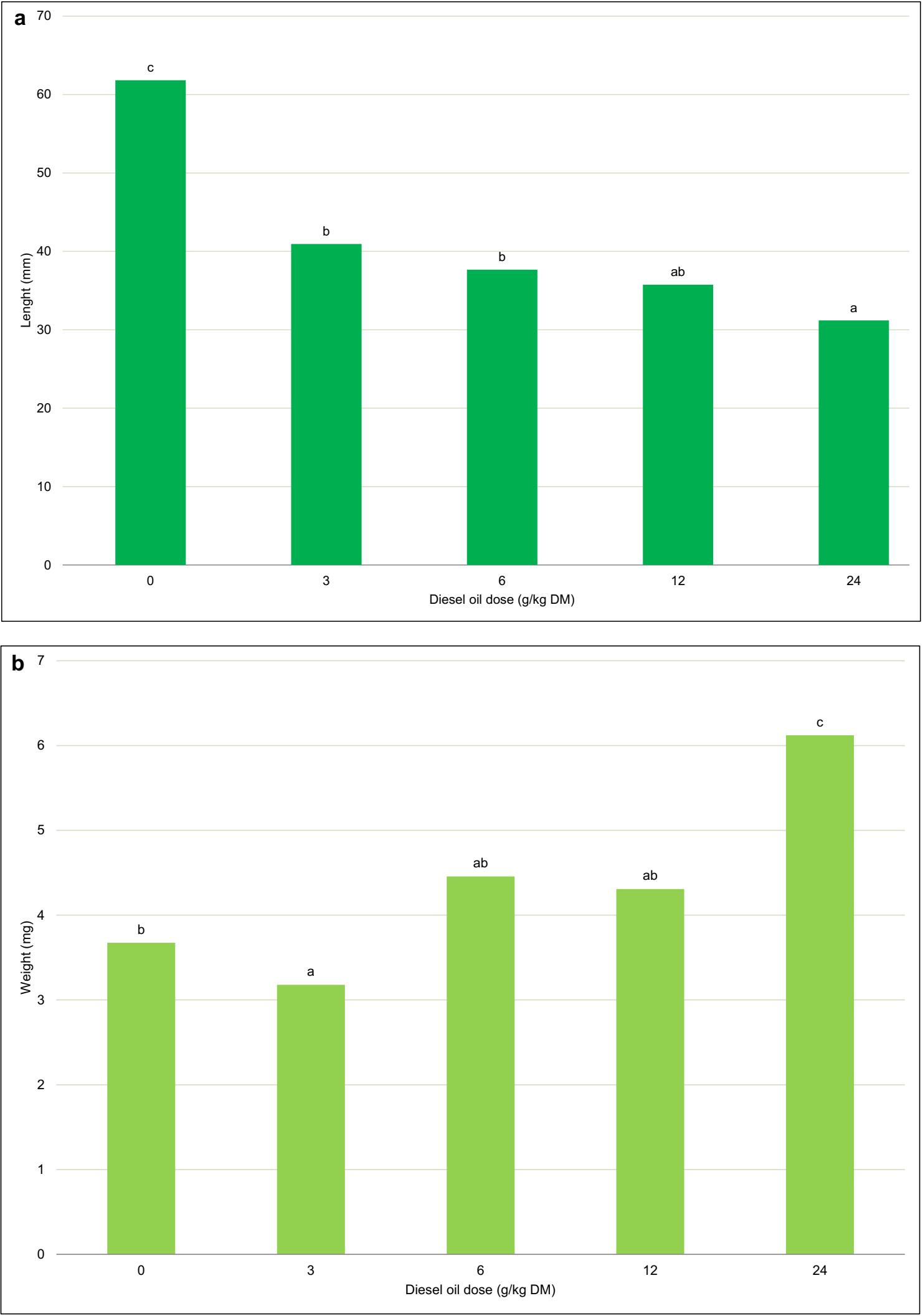

Fig. 4 Length (a) and weight (b) of Scots pine needles. Different letters above the columns indicated significant difference at the $p<0.05$ 


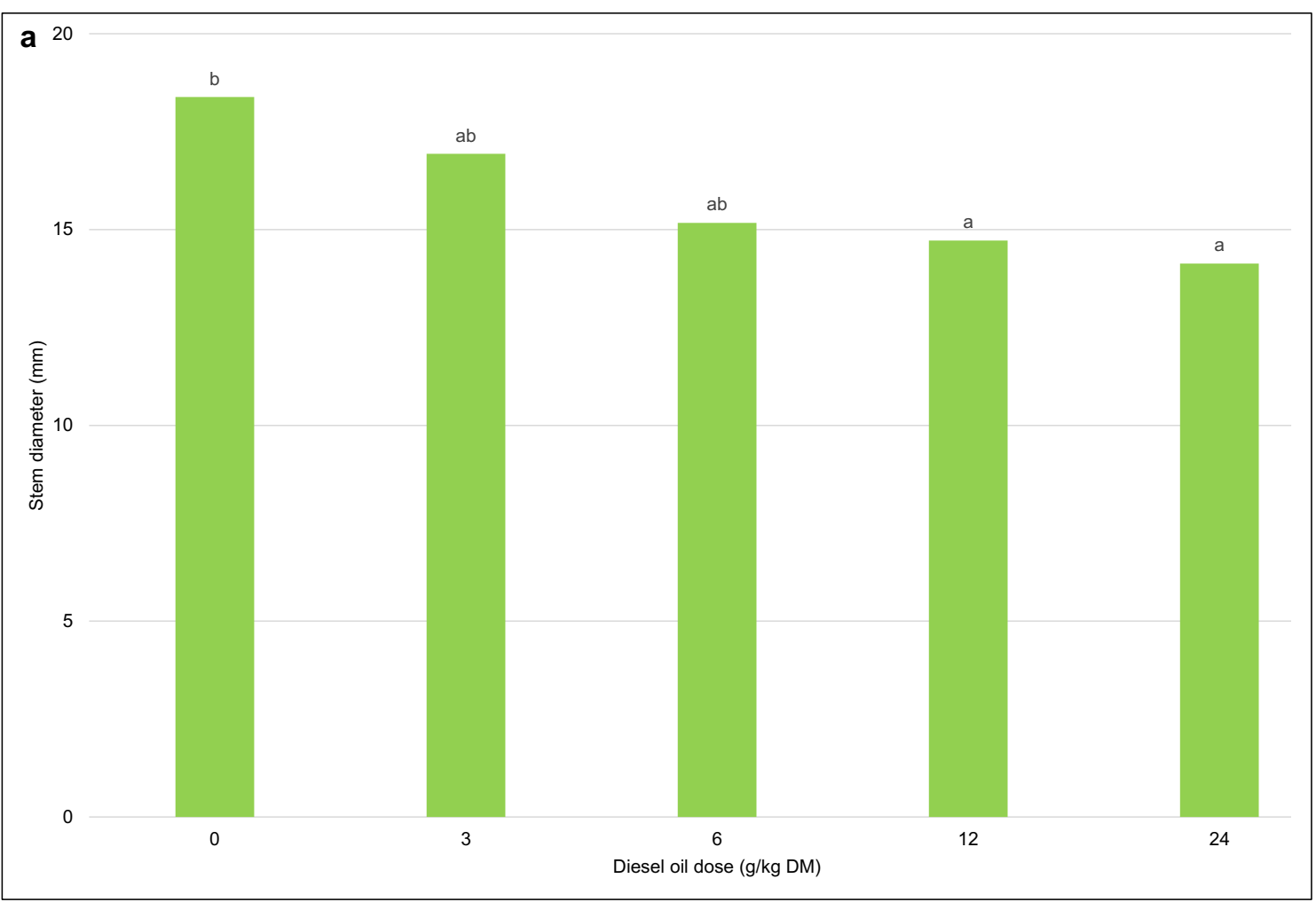

b 20

15

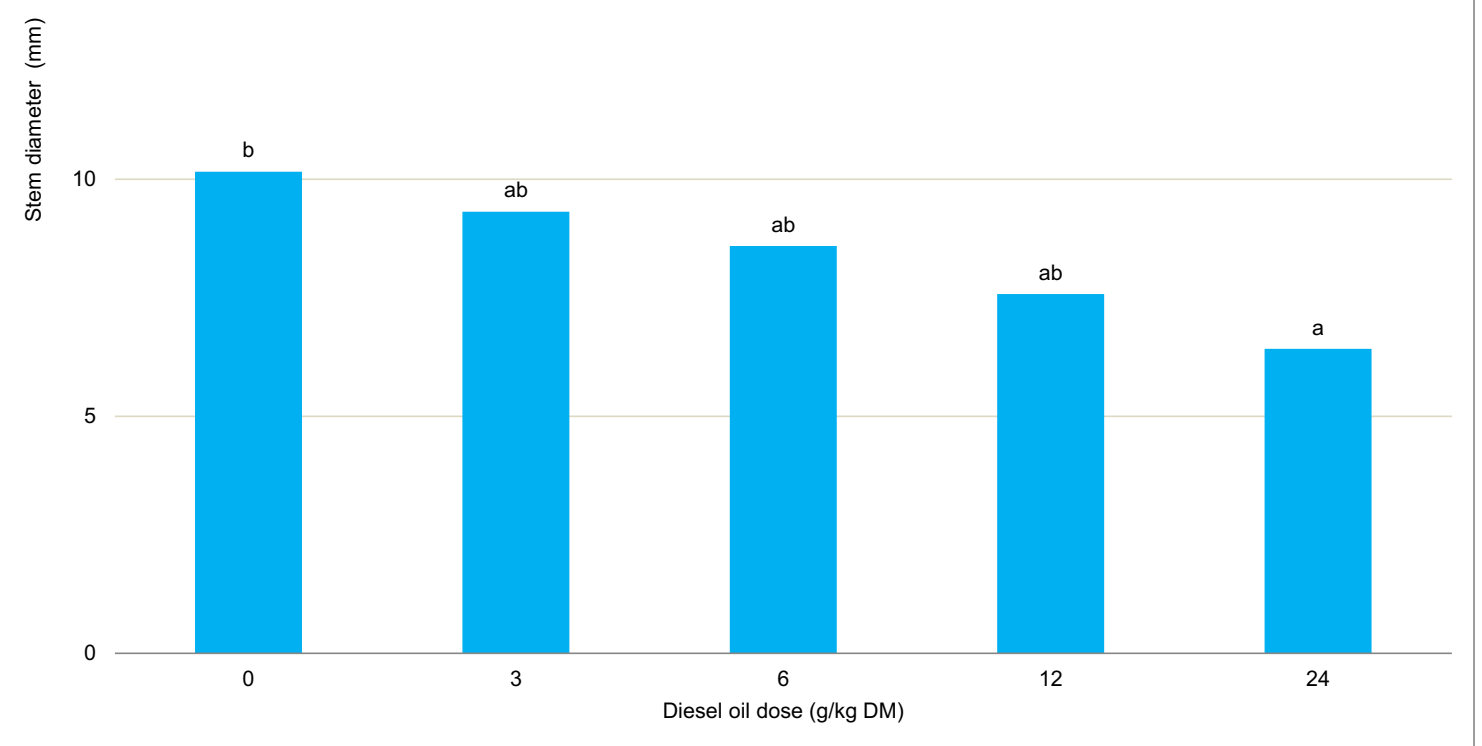

Fig. 5 Stem diameter of Scots pine (a) and European beech (b). Different letters above the columns indicated significant difference at the $p<0.05$ 


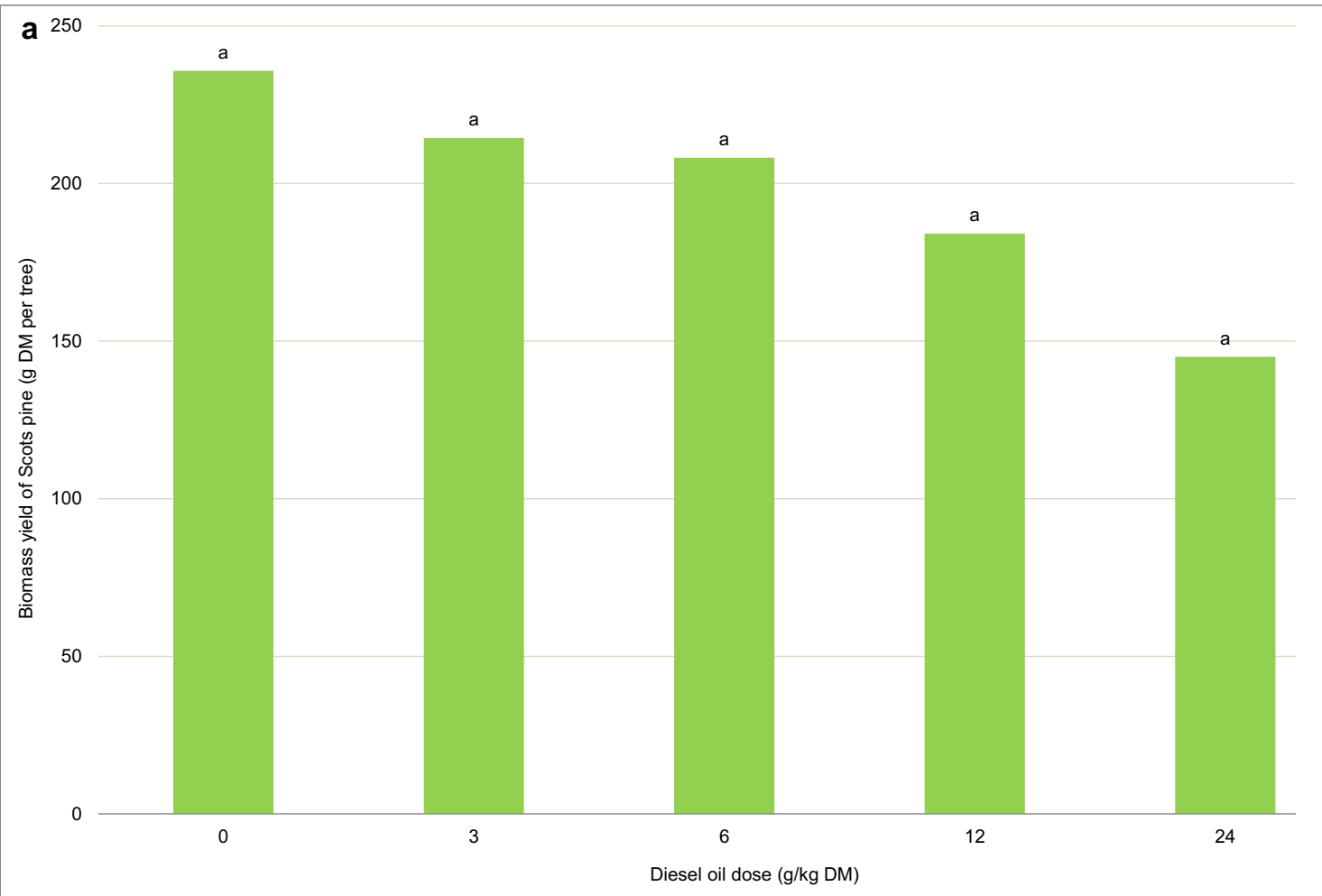

$$
\text { b } 60
$$

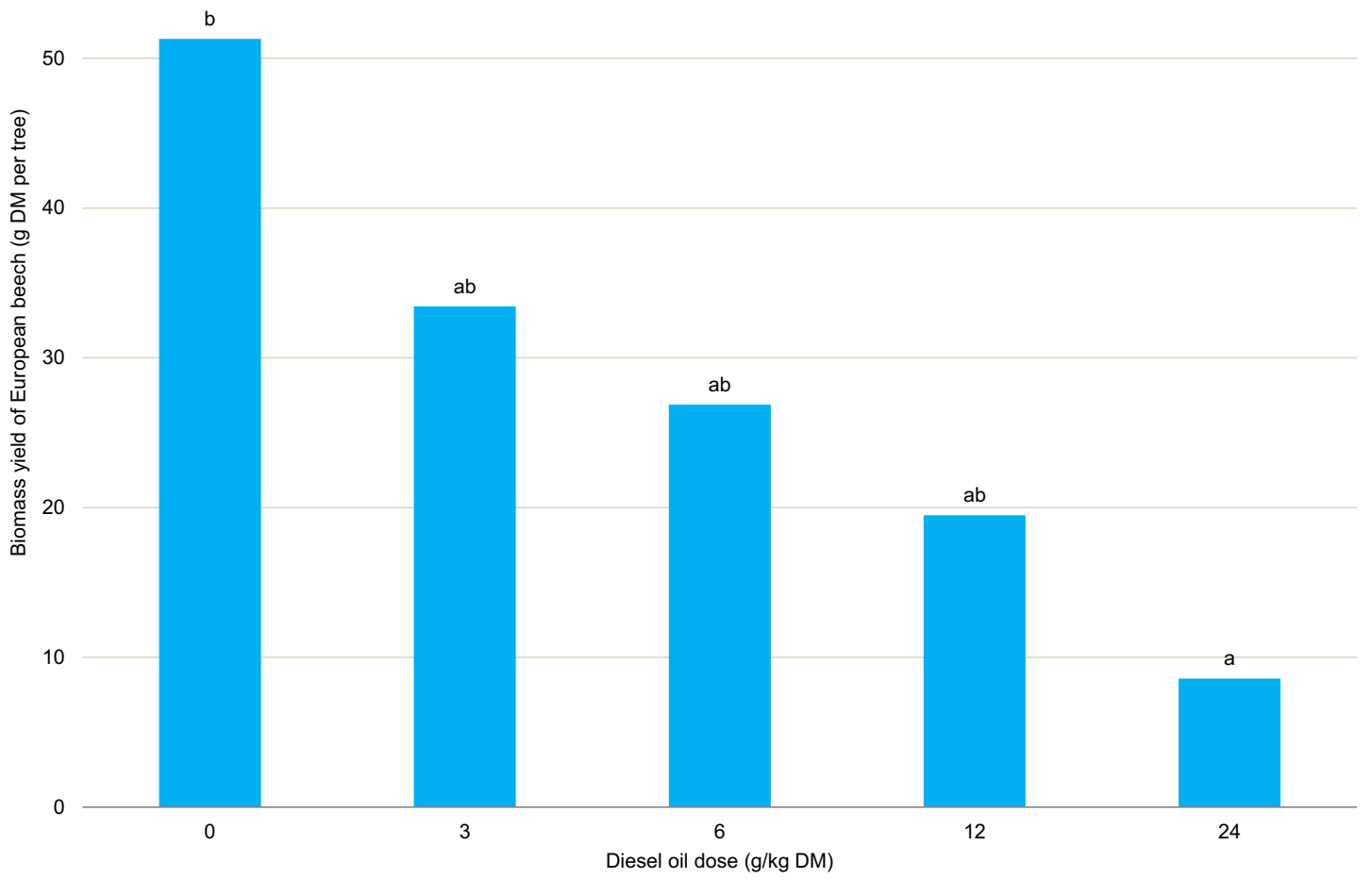

Fig. 6 The biomass yield of Scots pine (a) and European beech (b). Different letters above the columns indicated significant difference at the $p<0.05$ 
Table 3 Analysis of variance $(F$ test) of fluctuating asymmetry indicators - FAL and FAM

\begin{tabular}{llllll}
\hline Source of variation & Sum of squares & df & Mean square & $F$ & $p$ value \\
\hline FAL & & & & & \\
Intercept & 0.3623 & 1 & 0.3623 & $1039.2^{* * *}$ & $<0.001$ \\
O & 0.3130 & 4 & 0.0783 & $224.5^{* *}$ & $<0.001$ \\
Error & 0.0279 & 80 & 0.00033 & & \\
FAM & 1.9761 & & & & \\
Intercept & 0.1179 & 4 & 1.9761 & $11.6^{* * *}$ & $<0.001$ \\
O & 0.2028 & 80 & 0.0025 & & \\
Error & & 4 & 0.0295 & \\
\hline
\end{tabular}

$O$, diesel oil dose. *Significant at $p<0.05 ; * *$ significant at $p<0.01 ; n s$ not significant decreased with an increase in diesel oil dose in all experimental years. The analyzed parameter ranged from 0.67 (in 5 years) to 0.74 (in 1 year) in control plants, and from 0.57 (in 4 years and 5 years) to 0.66 (in 1 year) in the most contaminated treatment (Fig. 11). The results were validated by three-way ANOVA. The Fv/Fm ratio was significantly correlated with tree species, soil contamination level, and experimental year (Table 5). The analyzed parameter was higher in Scots pine needles (0.69) than in European beech leaves (0.65) (Fig. 11). In both tree species, the average Fv/Fm values decreased with increasing soil contamination levels. The analyzed parameter was $18 \%$ lower in the most contaminated treatment than in the control treatment (Fig. 11).

\section{Discussion}

The Scots pine is widespread across Northern and Central Europe, and Eastern Siberia. Its geographic range extends westward to Great Britain and Portugal, eastward to Eastern Siberia, southward to the Caucasus, and northward to the Arctic Circle in Scandinavia. The Scots pine is also the most abundant species of coniferous trees in north-eastern Europe (Eckenwalder 2009). In Poland, the species occupies more than $60 \%$ of forest area (Central Statistical Office 2017). The Scots pine thrives in nearly all types of habitats, on dry and infertile as well as fertile and moist soils (Muilu-Mäkelä et al. 2015). This pioneer species grows on nutrient-deficient soils, and it is the ideal candidate for soil reclamation, remediation, and reforestation in Central Europe (Pietrzykowski et al. 2013; Placek et al. 2016).

The European beech is one of the main species of forest trees in western and southern Poland. In Europe, its geographic range stretches from the northern Iberian Peninsula through France, Germany, and Central Europe to the Balkans. The European beech is highly tolerant of soil acidification. It thrives on aerated and moist soils (Jarcuska 2009). The European beech is a species of high economic and ecological value, and it is sensitive to drought and spring frost (Pena et al. 2013; Pšidová et al. 2018). The development of European beeches growing on polluted soil for many years has never been described in the literature.

Petroleum and petroleum derivatives are the most ubiquitous pollutants in highly industrialized countries. Grasses, legumes, and trees (phytoremediation) are used to remove or neutralize these pollutants in the environment (soil and water). Phytoremediation can pose an alternative to other purification techniques because it does not modify soil properties (Cook and Hesterberg 2013; Burezq and Aliewi 2018). Phytoremediation methods rely on plant species that rapidly adapt to degraded environments and are capable of producing large quantities of biomass (Cook and Hesterberg 2013; Dudai et al. 2018). The Scots pine is one of such species (Placek et al. 2016), whereas the use of European beech for phytoremediation has not been described in the literature.

Diesel oil decreases the biomass yield of plants, and its effects are exacerbated with an increase in soil pollution (Leewis et al. 2013; Xi et al. 2018; Xie et al. 2018; Petrová et al. 2017; Bamgbose and Anderson 2015; Villacís et al. 2016). In our study, increasing doses of diesel oil reduced the biomass yield of European beech only. European beech was characterized by the lowest yield in the most contaminated treatment. The biomass yield of Scots pine was not significantly correlated with an increase in diesel oil dose, and it was more than $700 \%$ higher in comparison with European beech. The absence of significant differences in the yield of Scots pine grown on polluted soil for 8 years indicates that this species was more resistant to contamination than the European beech (Fig. 6). Other authors also demonstrated that the Scots pine well adapts to polluted environments. Scots pines growing in a former mining region for 30 years were characterized by higher yields than control trees 
a 0.25

0.20
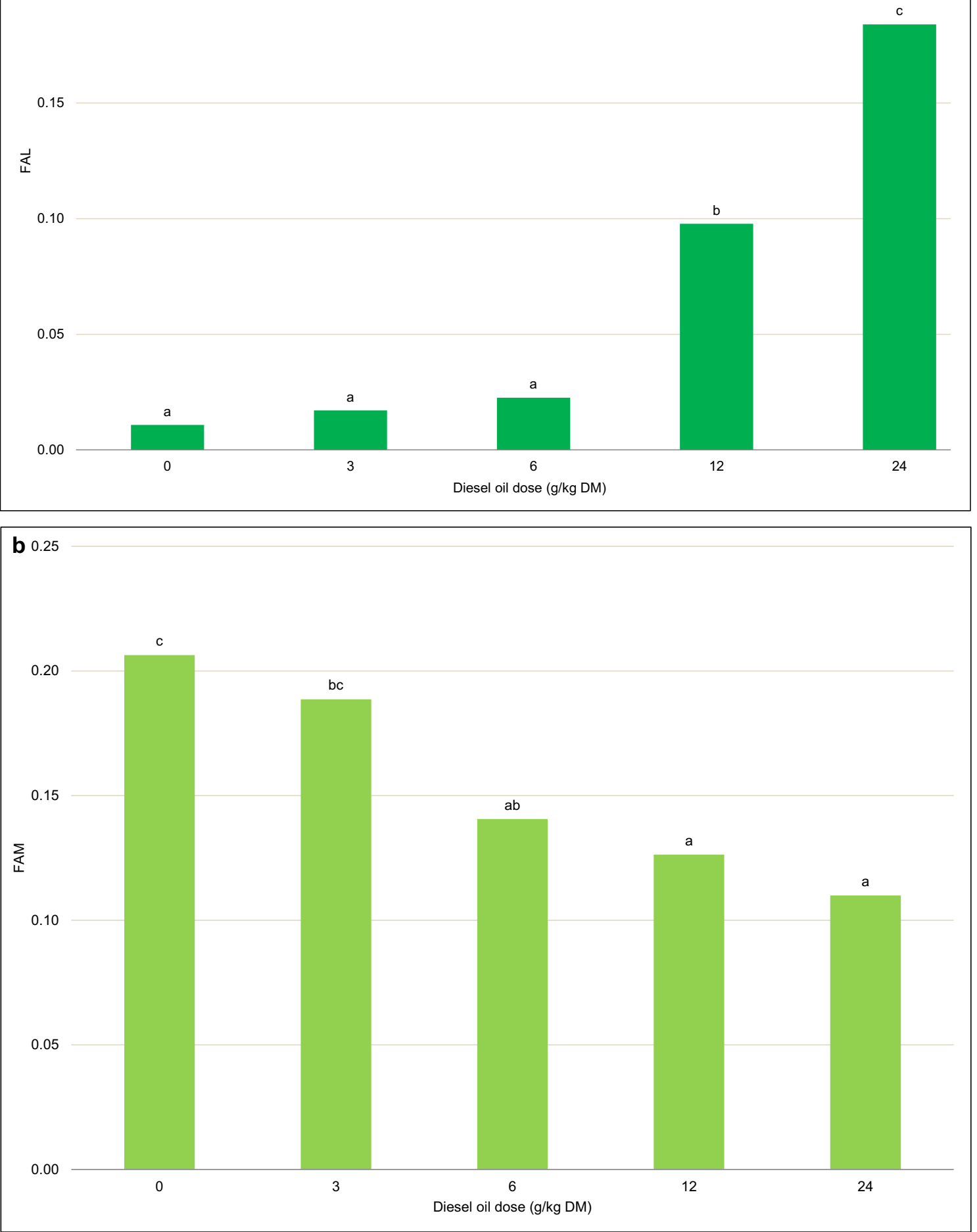

Fig. 7 Fluctuating asymmetry indicators -FAL and FAM. Different letters above the columns indicated significant difference at the $p<0.05$ 

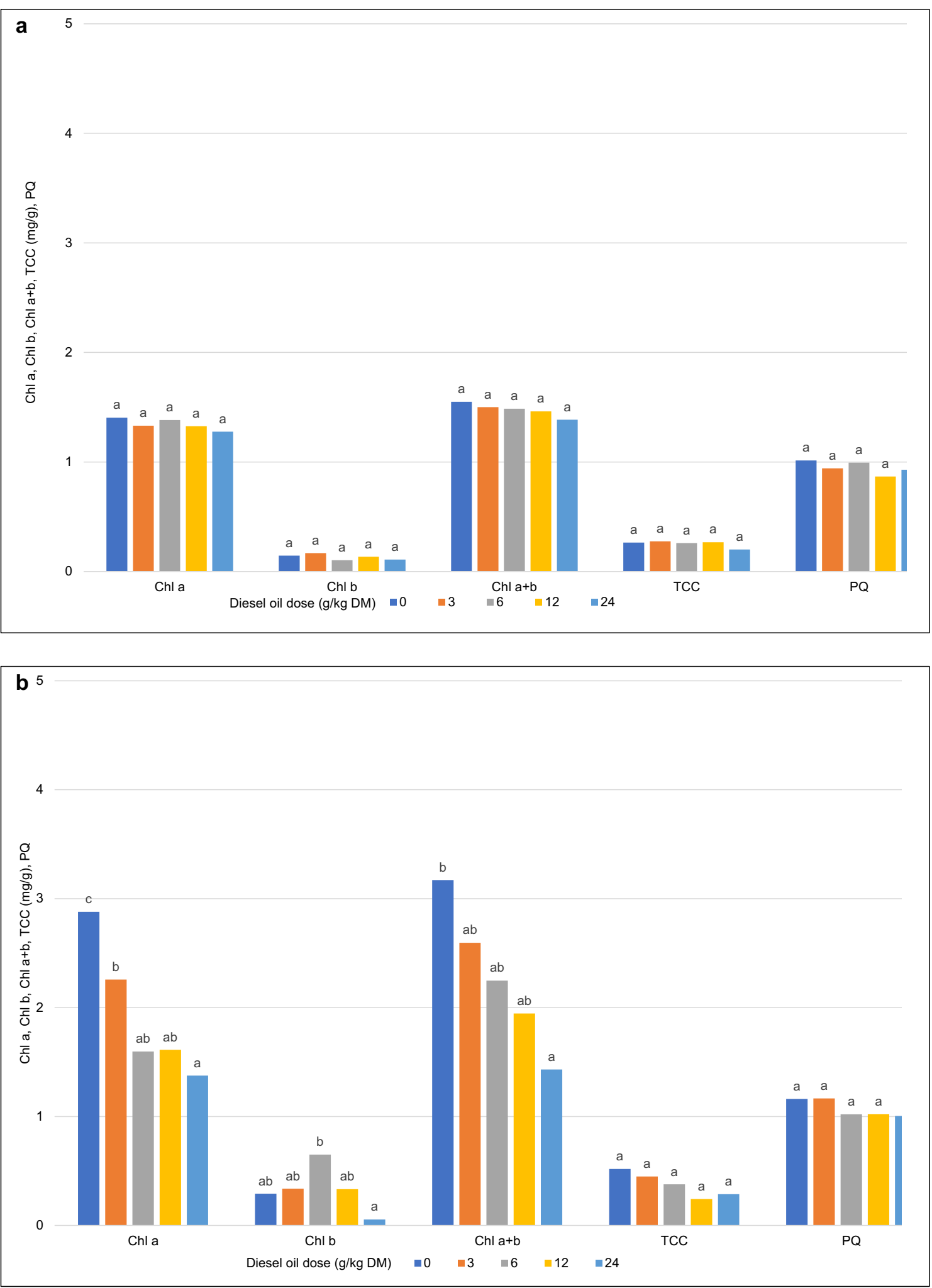

Fig. 8 The content of Chla, Chlb, Chla + b, TCC, and PQ and in Scots pine needles (a first year, c last year) and European beech leaves (b first year, d last year). Chla, chlorophyll a content; Chlb, chlorophyll b content; Chla $+\mathrm{b}$, the sum of chlorophylls a and b; TCC, total carotenoid content; PQ, phaeophytization quotient. Different letters above the columns indicated significant difference at the $p<0.05$ 

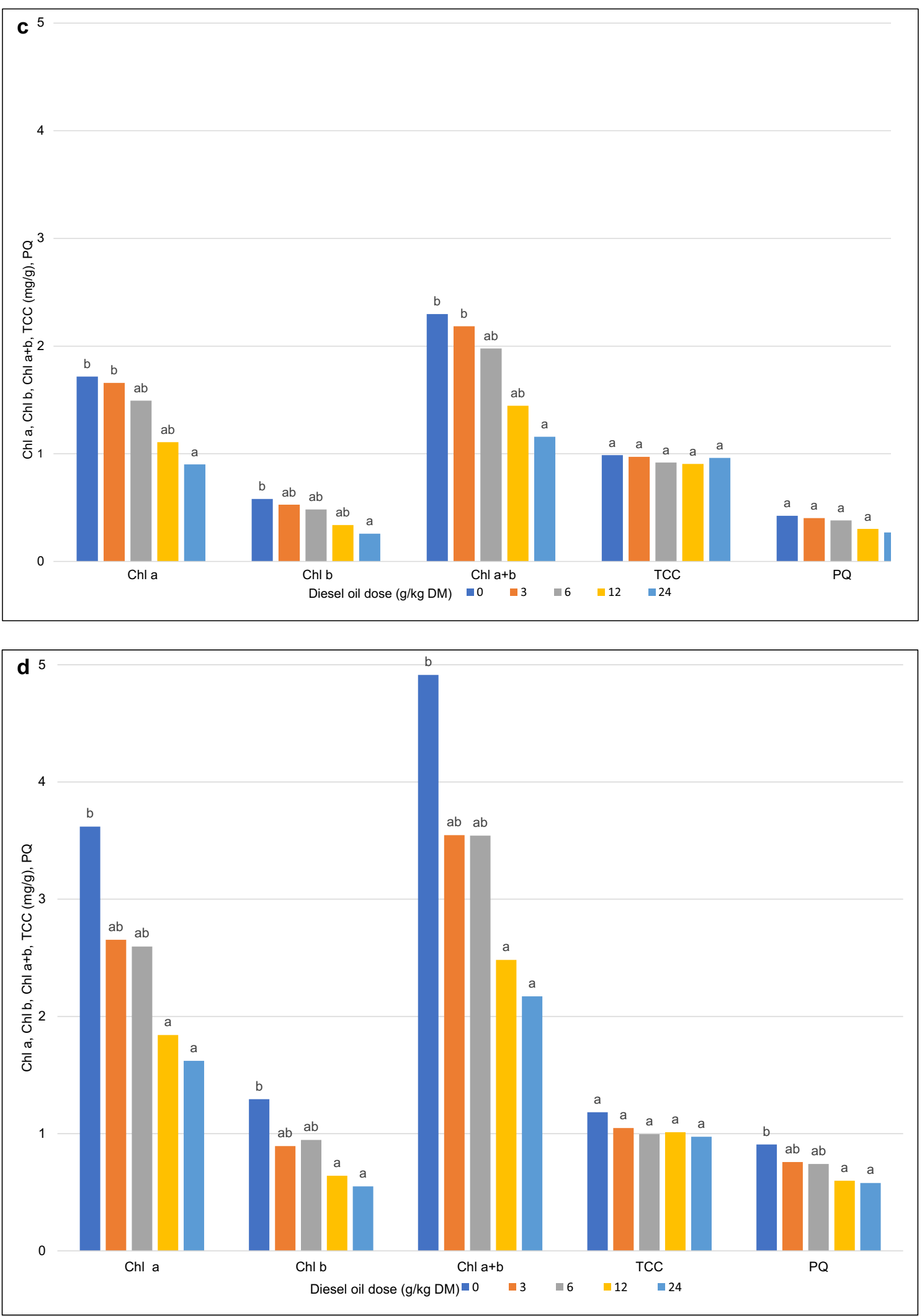

Fig. 8 (continued) 


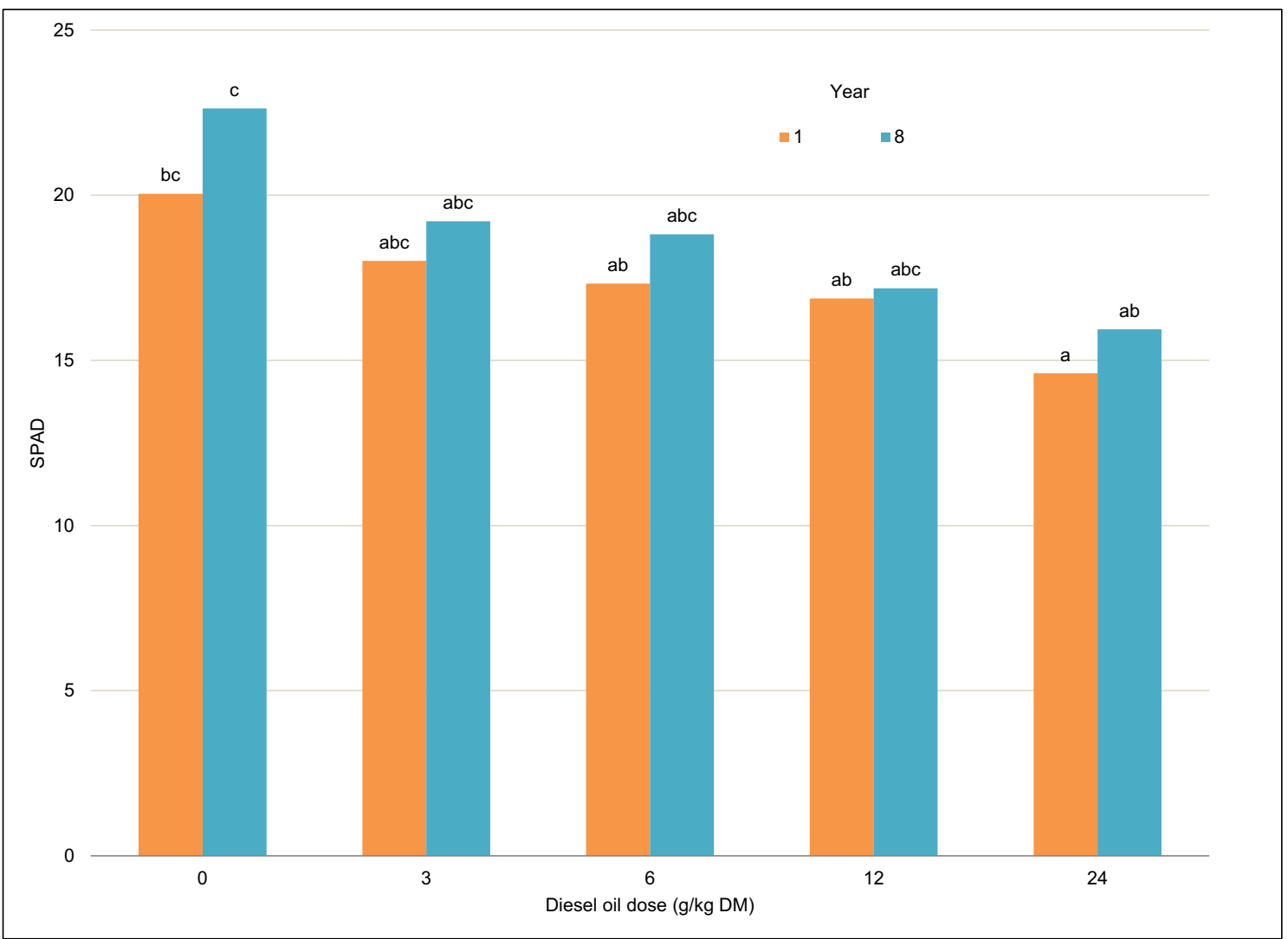

Fig. 9 Leaf greenness index (SPAD) of European beech leaves. Different letters above the columns indicated significant difference at the $p<0.05$

(Pietrzykowski and Socha 2011). In southern Finland, where the Scots pine is the predominant tree species, this conifer was also resistant to chemical stress resulting from soil contamination with lead (Selonen and Setälä 2015). However, the biomass yield of Scots pine grown for 10 years on flotation sediments in south-west and mid-west Poland was reduced by 50\% (Mleczek et al. 2018).

The biomass yield of trees is determined mainly by biometric parameters such as tree height and stem diameter. In this experiment, Scots pines were taller and had thicker stems than European beeches after 8 years (Fig. 1; 5). Kuznetsova et al. (2010) also observed that Scots pines were taller than deciduous trees in degraded habitats. In the first and second year of the present experiment, Scots pines did not respond to contamination, and variations in height were observed from year 3 . In years 7 and 8 , significant differences in tree height were not observed, which could indicate that the Scots pine adapted to contaminated soil. In contrast, European beeches responded to diesel oil pollution already in the first year of the study. Significant differences in the height of European beeches exposed to different doses of diesel oil were observed throughout the experiment (Fig. 2). Palmroth et al. (2002) analyzed 1-year-old seedlings of Scots pine and eastern cottonwood on soil contaminated with diesel oil (at a
Table 4 Analysis of variance $(F$ test) of leaf greenness index (SPAD) of European beech leaves

\begin{tabular}{llllll}
\hline Source of variation & Sum of squares & df & Mean square & $F$ & $p$ value \\
\hline Intercept & $15,539.0733$ & 1 & $15,539.0733$ & $3758.2^{* * *}$ & $<0.001$ \\
O & 196.252325 & 4 & 49.0630812 & $11.9^{* *}$ & $<0.001$ \\
Y & 22.8147655 & 1 & 22.8147655 & $5.5^{* *}$ & $<0.001$ \\
O x Y & 6.00932462 & 4 & 1.50233116 & 0.4 n.s. & 0.833 \\
Error & 157.120059 & 38 & 4.13473839 & & \\
\hline
\end{tabular}

$O$, diesel oil dose; $Y$, year; $O \times Y$, interactions between the factors

*Significant at $p<0.05 ; * *$ significant at $p<0.01 ; n s$ not significant 


\section{a 0.90}

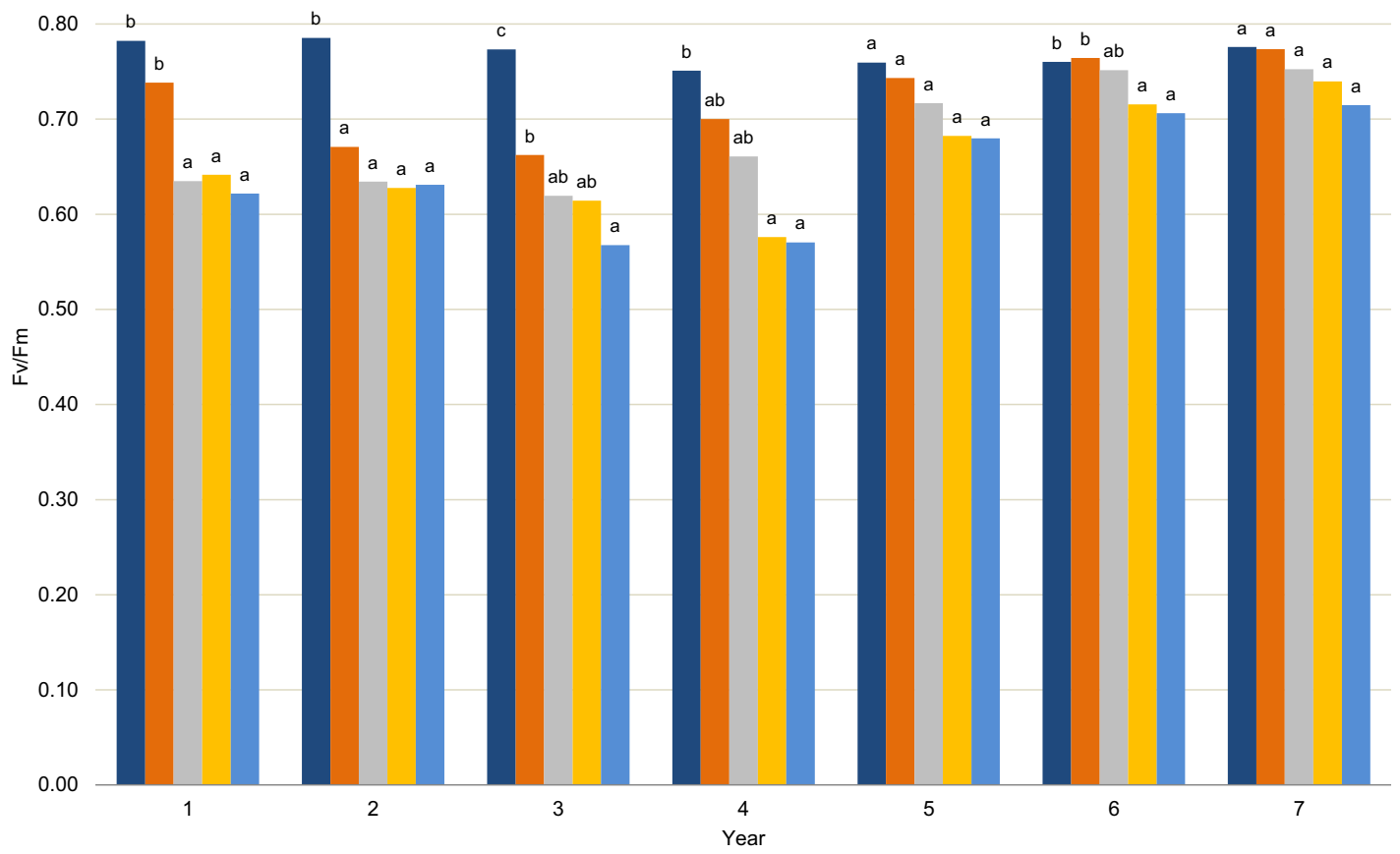

b 0.90

0.80

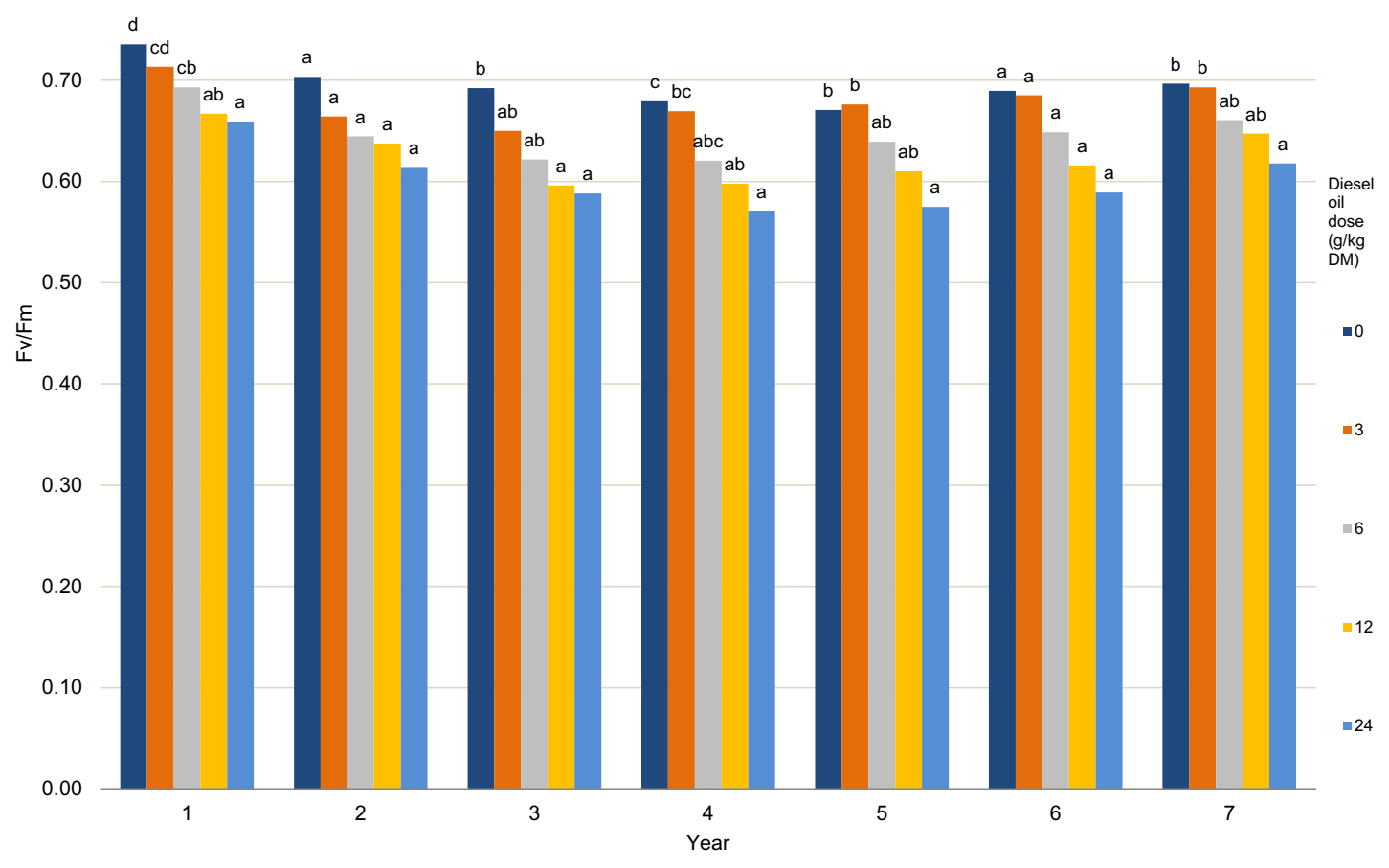

Fig. 10 Chlorophyll $a$ fluorescence - the Fv/Fm ratio of Scots pines (a) and European beech (b). Different letters above the columns indicated significant difference at the $p<0.05$ 


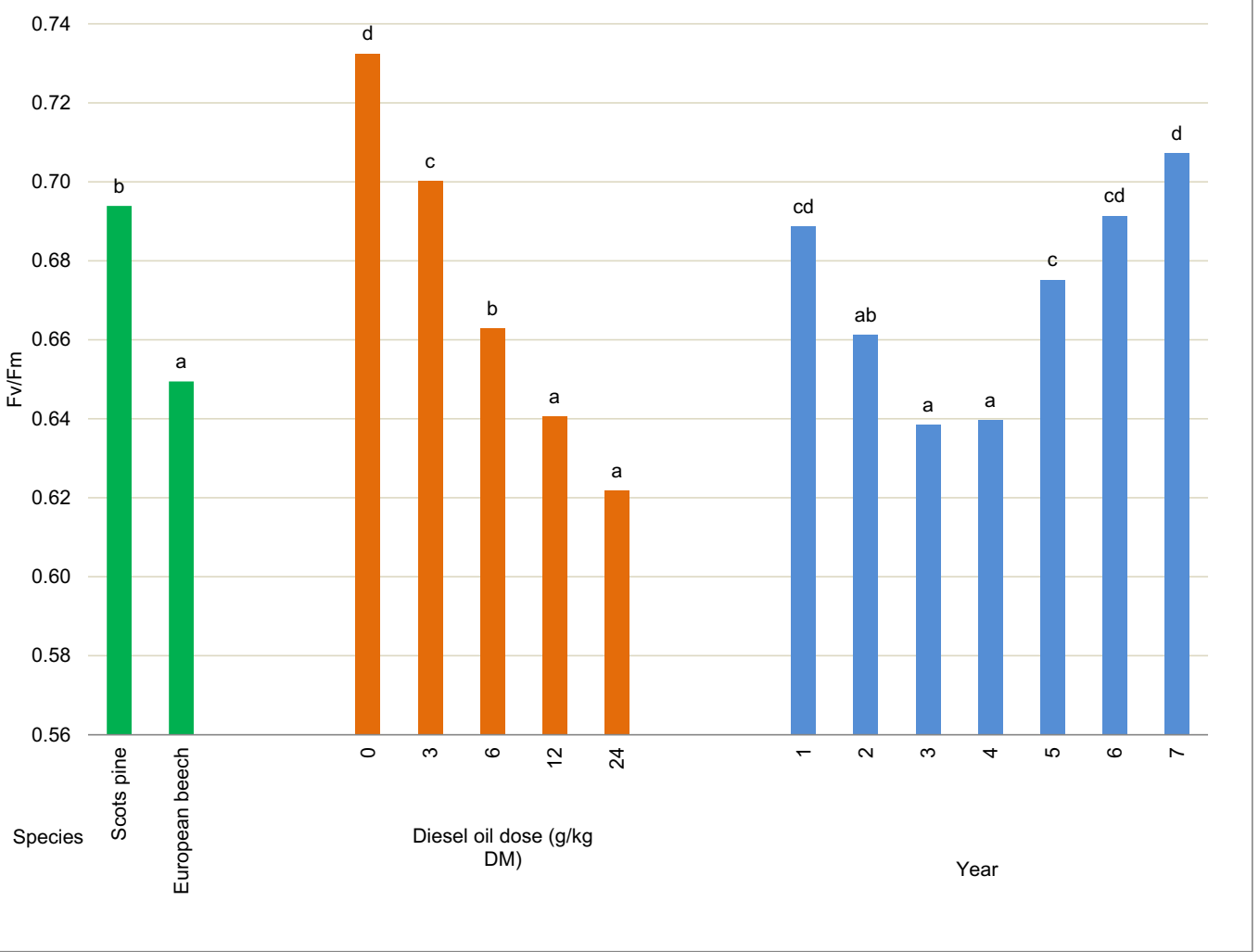

Fig. 11 Chlorophyll $a$ fluorescence (Fv/Fm ratio) depending on the tree species, the diesel oil dose, and the year of experiment. Different letters above the columns indicated significant difference at the $p<0.05$

concentration of $0.5 \%$ and $2.0 \%$ ). Poplar leaves were damaged in the treatment polluted with $0.5 \%$ diesel oil, and some seedlings did not survive in the treatment contaminated with $2.0 \%$ diesel oil. The Scots pine was more resistant to oil pollution. Needles were not damaged, and the length and annual increase in needle length were identical to those noted in control trees. In the first year of the experiment, the average increment in tree height was determined at $8 \mathrm{~cm}$ in Scots pines and $4.3 \mathrm{~cm}$ in European beeches (Fig. 4). The above suggests that the initial height increment influenced the growth performance of trees in the course of the 8-year-long experiment. Similar observations were made by Villacís et al. (2016). Diesel oil pollution also impaired the growth of plants in the tropical climate (Merkl et al. 2005; Shirdam et al. 2008).

The stem diameter in the analyzed tree species was significantly differentiated by the applied dose of diesel oil. In the most contaminated treatment, the stem diameter of Scots pines was 1.5-fold lower, and the stem diameter of European beeches was more than twice smaller than in the control treatment (Fig. 5). Acacia seedlings growing on soil contaminated with
Table 5 Analysis of variance $(F$ test) of chlorophyll $a$ fluorescence (Fv/Fm ratio)

\begin{tabular}{llllll}
\hline Source of variation & Sum of squares & df & Mean square & $F$ & $p$ value \\
\hline Intercept & 157.4247 & 1 & 157.4247 & $109,654.3^{* *}$ & $<0.001$ \\
$\mathrm{~S}$ & 0.1746 & 1 & 0.1746 & $121.6^{* *}$ & $<0.001$ \\
$\mathrm{O}$ & 0.5615 & 4 & 0.1404 & $97.8^{* *}$ & $<0.001$ \\
$\mathrm{Y}$ & 0.2114 & 6 & 0.0352 & $24.5^{* *}$ & $<0.001$ \\
$\mathrm{~S} \times \mathrm{O}$ & 0.0204 & 4 & 0.0051 & $3.5^{* *}$ & $<0.001$ \\
$\mathrm{~S} \times \mathrm{Y}$ & 0.1318 & 6 & 0.0220 & $15.3^{* *}$ & $<0.001$ \\
$\mathrm{O} \times \mathrm{Y}$ & 0.0776 & 24 & 0.0032 & $2.3^{* *}$ & $<0.001$ \\
$\mathrm{~S} \times \mathrm{O} \times \mathrm{Y}$ & 0.0478 & 24 & 0.0020 & $1.4 \mathrm{n} . \mathrm{s}$. & 0.112 \\
Error & 0.4005 & 279 & 0.0014 & & \\
\hline
\end{tabular}

$S$, species; $O$, diesel oil dose; $Y$, year; $S \times O, S \times Y, O \times Y, S \times O \times Y$, interactions between the factors

*Significant at $p<0.05 ; * *$ significant at $p<0.01 ; n s$ not significant 
diesel oil from a leaking underground pipe in the arid region of Arava in southern Israel were also characterized by a reduced stem diameter (Tran et al. 2018). In contrast, the stem diameter of five out of more than 20 tree species growing in oil fields in the Amazon drainage basin in Ecuador was greater than in the control species (Villacís et al. 2016).

The length of Scots pine needles from the most contaminated treatment was $50 \%$ smaller relative to control needles. However, the shortest needles were also heaviest (Fig. 4). The length, thickness, surface area, fresh and dry weight, and the number of leaf stomata per unit area are generally determined by light intensity (Kyć 1981). In north-eastern China, the anatomical, morphological, and physiological traits of leaves in shrubs, perennial grasses, and forbs were affected by differences in the utilization of water resources (Guo et al. 2017). High leaf thickness enables plants to maintain relatively high leaf water content during drought (Marenco et al. 2009; Seelig et al. 2015). Needle length in 6-week-old Scots pine seedlings growing on substrates with various zinc concentrations also decreased with a rise in zinc concentration (Ivanov et al. 2016). The needles of 1 -year-old Scots pine seedlings growing on soil contaminated with diesel oil $(0.5 \%$ and $2.0 \%)$ were not damaged, and the annual increment in needle length was similar to that noted in control needles (Palmroth et al. 2002). For this reason, Scots pine needles are often used in research as bioindicators of environmental contamination from various sources (Pająk et al. 2017).

In ecological studies, the FA values of leaves and needles are often analyzed as stress indicators (Fair and Breshears 2005; Cuevas-Reyes et al. 2018; Zvereva et al. 1997). The FA values of Scots pine needles exposed to radioactive elements (Geraskin et al. 2003; Kashparova et al. 2018), heavy metals (Kozlov and Niemelä 1999), air pollution (Kozlov et al. 2002), and water stress (Kozlov and Niemelä 2003) have been described in the literature. The fluctuating asymmetry index increases in response to stress, which was also confirmed in our study (Fig. 7). The FAL values of Scots pine needles were highest in the most contaminated treatments (12 and $24 \mathrm{~g}$ of diesel oil $/ \mathrm{kg}$ of soil DM). A reverse correlation was noted in the FAM values of needles which were highest in the least contaminated treatment (Fig. 7). Our results suggest that Scots pines growing on polluted soil for 8 years developed various adaptive strategies. Water accumulation in cells could be one of the strategies for minimizing the adverse effects of diesel oil. Plants rely on three common strategies for drought adaptation: escape, tolerance, and avoidance (Chaves et al. 2003). Soil contamination with high xenobiotic concentrations leads to physiological drought (Baciak et al. 2017). Excessive levels of sodium chloride in soil decrease osmotic potential and inhibit water uptake by plants (Wang et al. 2011; Yilmaz 2007; Sikorski et al. 2013).

The chlorophyll content of plants is one of the key indicators of growth, photosynthetic ability, productivity, and stress tolerance. Chlorophyll concentrations decrease under exposure to stressors such as gas pollution (Lange et al. 2004; Nevalainen et al. 2014; Sakugawa and Cape 2007), oxidative stress (Biczak 2016), and heavy metals (Costa et al. 2018; Xiong et al. 2018). In our experiment, diesel oil decreased the concentrations of chlorophylls $a$ and $b$ (Fig. 8). Plant growth was probably inhibited by chlorophyll degradation during its biosynthesis. Diesel oil can suppress chlorophyll synthesis, which decreases the content of chlorophylls $a$ and $b$ (Wang et al. 2011). The concentrations of photosynthetic pigments were also reduced in Scots pines exposed to air pollution (Joshi and Swami 2009).

The content of chlorophyll $a$ in Scots pine needles was measured in the first ( 2 months after soil contamination) and last year of the study (before biomass harvest). The concentrations of chlorophylls $a$ and $b$, carotenoids, total chlorophyll, and the phaeophytization quotient remained unchanged during the first measurement (Fig. 8). The above suggests that the synthesis of photosynthetic pigments was not inhibited in plants growing on polluted soil for only 2 months. In contrast, the content of assimilation pigments in Scots pine needles and European beech leaves was correlated with the applied xenobiotic dose after 8 years of exposure. Chlorophyll content was lowest in Scots pine needles grown in the most contaminated treatment. Control needles and needles from the least contaminated treatment $(3 \mathrm{~g} / \mathrm{kg})$ were characterized by comparable chlorophyll levels of 1.72 and $1.66 \mathrm{mg} / \mathrm{g} \mathrm{FW}$, respectively. Similar results were reported by Wang et al. (2011) in soil containing the smallest doses of diesel oil (1, 5, and $10 \mathrm{~g} / \mathrm{kg}$ ). The chlorophyll content of reed plants increased, which suggests that the analyzed species was tolerant of diesel oil, in particular at lower concentrations. However, the content of total chlorophyll and chlorophylls $a$ and $b$ decreased in treatments where contamination levels exceeded $15 \mathrm{~g} / \mathrm{kg}$. The observed responses to low contamination levels indicate that plants rely on diesel oil as a source of components for the synthesis of selected enzymes (Wang et al. 2011). In our study, the content of chlorophyll $a$ in Scots pine needles from all contaminated treatments was $68 \%$ higher than the content of chlorophyll $b$. In needles collected from the most contaminated treatment, the concentration of chlorophyll $b$ was $45 \%$ lower than in control needles. The differences in carotenoid content were not statistically significant. Total chlorophyll content was similar to the concentration of chlorophyll $a$ (Fig. 8).

The European beeches are angiosperms, whereas Scots pines are gymnosperms. The leaves of the analyzed tree species differ in anatomy and morphology, but chlorophyll synthesis, initiation of chloroplast development, and the expression of genes encoding light-harvesting chlorophylls $a / b$ are determined by light exposure in both species (Chinn and Silverthorne 1993; Sarijeva et al. 2007). European beech leaves differ in sensitivity to UV-B subject 
to habitat conditions (natural and experimental) (Láposi et al. 2009), whereas forest seedlings are better adapted for lower levels of UV-B radiation than older trees (Grant et al. 2005). Sarijeva et al. (2007) analyzed leaf and chloroplast adaptation to light and shade and concluded that European beech was more resistant to both insolation and shade than Ginkgo biloba L.

European beech leaves contained more chlorophylls $a$ and $b$ than Scots pine needles, both in the first (difference of 35\%) and the last year of the study (45\%). Chlorophyll $a$ content was lowest in leaves from treatments contaminated with the two highest doses of diesel oil (49\% in the first year, and 55\% in the last year of the experiment).

The chlorophyll content of Accacia raddiana leaves growing on soil contaminated with diesel oil was reduced by $70 \%$ (Tran et al. 2018). In our study, the concentrations of carotenoids and chlorophylls $a$ and $b$ in European beech leaves also decreased with increasing diesel oil doses, both in the first and the last year of the experiment. Carotenoid content decreased by $44 \%$ and $18 \%$, and total chlorophyll content was reduced by $50 \%$ and $55 \%$ in the first and last year of the study, respectively. The content of photosynthetic pigments in Mimosa caesalpiniaefolia, Erythrina speciosa, and Schizolobium parahyba also decreased under exposure to lead (Ribeiro de Souza et al. 2012).

Similarly to chlorophyll $a$ content, the greenness index of European beech leaves decreased with a rise in diesel oil dose. The greenness index of alfalfa and bristle grass growing on oil-contaminated soil also decreased in a study by Xie et al. (2018). The greenness index and chlorophyll $a$ content of European beech leaves increased after 8 years of exposure to diesel oil (Fig. 9). The above suggests that the health status of European beeches improved in the last year of the experiment.

Chlorophyll fluorescence is a reliable indicator of plant stress, but it does not support the identification of different stress types. Fluorescence measurements are performed to evaluate the overall physiological status of plants before the first symptoms of leaf damage become apparent. Fluorescence intensity changes in response to the duration and intensity of stress (Dąbrowski et al. 2016; Kalaji et al. 2018). The Fv/Fm ratio is a reliable indicator of the photochemical activity of the photosynthetic apparatus. The above parameter measures the efficiency of light utilization in the initial stages of photosynthesis, and its value is proportional to the maximum quantum yield of PSII (Baker et al. 2001; Lawson et al. 2002). In healthy leaves, the maximum quantum yield of PSII ( Fv/ Fm) ranges from 0.76 to 0.85 (Percival et al. 2006). A decrease in the value of the above parameter testifies to plant stress. Very low values of Fv/Fm (0.2-0.3) are indicative of irreversible changes in the structure of PSII (Banks 2018; Kalaji et al. 2018; Percival et al. 2006; Sakugawa and Cape 2007). Rapid fluorescence measurements conducted with the use of various techniques indicate that environmental stressors induce specific photosynthetic responses in trees (Pšidová et al. 2018).

The Fv/Fm ratio is the most popular measure of chlorophyll fluorescence (Papageorgiou 2010). Two related ratios, $\mathrm{Fv} / \mathrm{Fm}$ and $\mathrm{Fv} / \mathrm{Fo}$, and the decrease in $\mathrm{Chl}$ fluorescence are often used to determine the potential quantum yield of PSII (Lichtenthaler and Babani 2004). Photosynthetic efficiency expressed by the $\mathrm{Fv} / \mathrm{Fm}$ ratio was determined at 0.7 in healthy pine needles growing under field conditions (Salmela et al. 2011). In Scots pine needles fumigated with nitrous acid (HONO), the $\mathrm{Fv} / \mathrm{Fm}$ ratio decreased significantly relative to control needles (Sakugawa and Cape 2007). In our experiment, the Fv/Fm ratio of Scots pine needles decreased with a rise in soil contamination in the first, second, third, and fourth year of the study. However, the differences in the $\mathrm{Fv} / \mathrm{Fm}$ values of needles from treatments contaminated with different doses of diesel oil were less pronounced in the fifth, sixth, and seventh year of the experiment. In the last year, the $\mathrm{Fv} / \mathrm{Fm}$ ratio of needles ranged from 0.7 to 0.8 , which indicates that the trees were in good condition.

The Scots pine was characterized by higher values of $\mathrm{Fv} /$ Fm, which could suggest that this species was more resistant to increasing levels of pollution than the European beech (Fig. 10). The European beech responded to contamination already in the first year of the study, and a minor decrease in $\mathrm{Fv} / \mathrm{Fm}$ values was observed in successive years. However, the health status of European beeches did not improve to the extent noted in Scots pines. The morphological and physiological parameters of European beeches were compromised under exposure to increasing concentrations of diesel oil. A decrease in $\mathrm{Fv} / \mathrm{Fm}$ values was observed in water-stressed European beeches and maples (Pšidová et al. 2018; Banks 2018) and in the leaves of the Pará rubber tree infected with fungi (Sterling and Melgarejo 2018). A study of selected tree and shrub species, including Betula pendula Roth, Sorbus intermedia Ehrh., Physocarpus opulifolius [L.] Maxim., Spiraea japonica L., and Hedera helix L., exposed to high levels of particulate matter pollution in downtown Warsaw revealed a decrease in $\mathrm{Fv} / \mathrm{Fm}$ values of with a rise in contamination levels. The Fv/Fm ratio decreased in all evaluated plants, but Hedera helix L. was the most sensitive species (Popek et al. 2018). The maximum quantum yield of PSII ( $\mathrm{Fv} / \mathrm{Fm}$ ) also decreased in eucalyptus trees exposed to $\mathrm{Cd}$ (Pietrini et al. 2015). The Fv/Fm ratio of willows (Salix fragilis $(\mathrm{Sf})$ and Salix aurita $(\mathrm{Sa}))$ decreased after 100 days of exposure to metals $(\mathrm{Zn}, \mathrm{Cu}, \mathrm{Cd}, \mathrm{Ni})$ relative to control (Evlard et al. 2014).

Plants respond differently to the presence of toxic substances in the environment, and phytotoxicity results from the interactions between chemical compounds and plants growing under specific environmental conditions. Chemical compounds cause morphological deformations and induce quantitative and qualitative changes in various 
plant organs (Tran et al. 2018; Wang et al. 2011; Sikorski et al. 2013).

\section{Conclusions}

Our findings confirmed the hypothesis that soil contamination with diesel oil induces various changes in the morphological and physiological properties of European beeches and Scots pines.

The Scots pine better adapts (grows more rapidly and produces higher biomass) to long-term soil contamination with diesel oil than the European beech. The results of this study suggest that the Scots pine is a potential candidate species for soil phytoremediation.

In European beeches, growth inhibition and leaf discoloration (a decrease in chlorophyll content) were observed already after the first year of the experiment, which indicates that 1-year-old seedlings of European beech are robust bioindicators of soil contamination with diesel oil.

Funding information This study was supported by the Ministry of Science and Higher Education of Poland as part of statutory activities (no. 20.610.027-300).

Open Access This article is distributed under the terms of the Creative Commons Attribution 4.0 International License (http://creativecommons.org/ licenses/by/4.0/), which permits unrestricted use, distribution, and reproduction in any medium, provided you give appropriate credit to the original author(s) and the source, provide a link to the Creative Commons license, and indicate if changes were made.

Publisher's note Springer Nature remains neutral with regard to jurisdictional claims in published maps and institutional affiliations.

\section{References}

Baciak M, Sikorski Ł, Piotrowicz-Cieślak AI, Adomas B (2017) Role of decarboxylases in the biosynthesis of biogenic amines of pea growing in soil contaminated with lomefloxacin. Appl Ecol Environ Res 15(3):1131-1148. https://doi.org/10.15666/aeer/1503_11311148

Baker NR, Oxborough K, Lawson T, Morison JIL (2001) High resolution imaging of photosynthetic activities of tissues, cells and chloroplasts in leaves. J Exp Bot 52(356):615-621. https://doi.org/10.1093/jxb/ 52.356 .615

Bamgbose I, Anderson TA (2015) Phytotoxicity of three plant-based biodiesels, unmodified castor oil, and diesel fuel to alfalfa (Medicago sativa L.), lettuce (Lactuca sativa L.), radish (Raphanus sativus), and wheatgrass (Triticum aestivum). Ecotoxicol Environ Saf 122:268-274. https://doi.org/10.1016/j. ecoenv.2015.08.003

Banks JM (2018) Chlorophyll fluorescence as a tool to identify drought stress in Acer genotypes. Environ Exp Bot 155:118-127. https://doi. org/10.1016/j.envexpbot.2018.06.022

Barnes JD, Balaguer L, Manrique E, Elvira S, Davison AW (1992) A reappraisal of the use of DMSO for the extraction and determination of chlorophylls $\mathrm{a}$ and $\mathrm{b}$ in lichens and higher plants. Environ Exp Bot 32(2):85-100. https://doi.org/10.1016/0098-8472(92)90034-Y
Biczak R (2016) Quaternary ammonium salts with tetrafluoroborate anion: phytotoxicity and oxidative stress in terrestrial plants. J Hazard Mater 304:173-185. https://doi.org/10.1016/j.jhazmat.2015.10.055

Bona C, de Rezende IM, Santos GO, de Souza LA (2011) Effect of soil contaminated by diesel oil on the germination of seeds and the growth of Schinus terebinthifolius Raddi (Anacardiaceae) Seedlings. Braz Arch Biol Technol 54(6):1379-1387. https://doi. org/10.1590/S1516-89132011000600025

Burezq H'A, Aliewi A (2018) Using phytoremediation by decaying leaves and roots of reed (Phragmites austrates) plant uptake to treat polluted shallow groundwater in Kuwait. Environ Sci Pollut Res Int. https://doi.org/10.1007/s11356-018-3385-0

Central Statistical Office (2017) Forestry. Statistical Publishing Establishment

Chai S, Shi J, Huang T, Guo Y, Wei J, Guo M, Li L, Dou S, Liu L, Liu G (2018) Characterization of Chlorella sorokiniana growth properties in monosaccharide-supplemented batch culture. PLoS One 13(7): e0199873. https://doi.org/10.1371/journal.pone.0199873

Chakraborty T, Saha S, Matzarakis A, Reif A (2017) Influence of multiple biotic and abiotic factors on the crown die-back of European beech trees at their drought limit. Flora 229:58-70. https://doi.org/10. 1016/j.flora.2017.02.012

Chaves MM, Maroco JP, Pereira JS (2003) Understanding plant responses to drought - from genes to the whole plant. Funct Plant Biol 30(3):239. https://doi.org/10.1071/FP02076

Chinn E, Silverthorne J (1993) Light-dependent chloroplast development and expression of a light-harvesting chlorophyll $\mathrm{a} / \mathrm{b}$-binding protein gene in the gymnosperm Ginkgo biloba. Plant Physiol 103(3):727732. https://doi.org/10.1104/pp.103.3.727

Cook RL, Hesterberg D (2013) Comparison of trees and grasses for rhizoremediation of petroleum hydrocarbons. Int J Phytoremediation 15(9):844-860. https://doi.org/10.1080/ 15226514.2012.760518

Costa MB, Tavares FV, Martinez CB, Colares IG, Martins CMG (2018) Accumulation and effects of copper on aquatic macrophytes Potamogeton pectinatus L.: potential application to environmental monitoring and phytoremediation. Ecotoxicol Environ Saf 155:117124. https://doi.org/10.1016/j.ecoenv.2018.01.062

Cuevas-Reyes P, Canché-Delgado A, Maldonado-López Y, Fernandes GW, Oyama K, González-Rodríguez A (2018) Patterns of herbivory and leaf morphology in two Mexican hybrid oak complexes: importance of fluctuating asymmetry as indicator of environmental stress in hybrid plants. Ecol Indic 90:164-170. https://doi.org/10.1016/j. ecolind.2018.03.009

Dąbrowski P, Baczewska AH, Pawluśkiewicz B, Paunov M, Alexantrov V, Goltsev V, Kalaji MH (2016) Prompt chlorophyll a fluorescence as a rapid tool for diagnostic changes in PSII structure inhibited by salt stress in Perennial ryegrass. J Photochem Photobiol B 157:2231. https://doi.org/10.1016/j.jphotobiol.2016.02.001

Derome J, Saarsalmi A (1999) The effect of liming and correction fertilisation on heavy metal and macronutrient concentrations in soil solution in heavy-metal polluted scots pine stands. Environ Pollut 104(2):249-259. https://doi.org/10.1016/S0269-7491(98)00183-3

Domínguez-Barroso MV, Herrera C, Larrubia MA, Alemany LJ (2016) Diesel oil-like hydrocarbon production from vegetable oil in a single process over $\mathrm{Pt}-\mathrm{Ni} / \mathrm{Al} 2 \mathrm{O} 3$ and $\mathrm{Pd} / \mathrm{C}$ combined catalysts. Fuel Process Technol 148:110-116. https://doi.org/10.1016/j.fuproc. 2016.02.032

Dudai N, Tsion I, Shamir SZ, Nitzan N, Chaimovitsh D, Shachter A, Haim A (2018) Agronomic and economic evaluation of Vetiver grass (Vetiveria zizanioides L.) as means for phytoremediation of diesel polluted soils in Israel. J Environ Manag 211:247-255. https://doi.org/10.1016/j.jenvman.2018.01.013

Eckenwalder JE (2009) Conifers of the world. The complete reference, 1. ed. Timber Press, Portland 
Evlard A, Sergeant K, Printz B, Guignard C, Renaut J, Campanella B, Paul R, Hausman J-F (2014) A multiple-level study of metal tolerance in Salix fragilis and Salix aurita clones. J Proteome 101:113129. https://doi.org/10.1016/j.jprot.2014.02.007

Fair JM, Breshears DD (2005) Drought stress and fluctuating asymmetry in Quercus undulata leaves: confounding effects of absolute and relative amounts of stress? J Arid Environ 62(2):235-249. https:// doi.org/10.1016/j.jaridenv.2004.11.010

Garbisu C, Hernández-Allica J, Barrutia O, Alkorta I, Becerril JM (2002) Phytoremediation: a technology using green plants to remove contaminants from polluted areas. Rev Environ Health 17(3):173-188

Gazol A, Camarero JJ, Jiménez JJ, Moret-Fernández D, López MV, Sangüesa-Barreda G, Igual JM (2018) Beneath the canopy: linking drought-induced forest die off and changes in soil properties. For Ecol Manag 422:294-302. https://doi.org/10.1016/j. foreco.2018.04.028

Geraskin SA, Zimina LM, Dikarev VG, Dikareva NS, Zimin VL, Vasiliyev DV, Oudalova AA, Blinova LD, Alexakhin RM (2003) Bioindication of the anthropogenic effects on micropopulations of Pinus sylvestris, L. in the vicinity of a plant for the storage and processing of radioactive waste and in the Chernobyl NPP zone. J Environ Radioact 66(1-2):171-180. https://doi.org/10.1016/S0265931X $(02) 00122-4$

Grant RH, Apostol K, Gao W (2005) Biologically effective UV-B exposures of an oak-hickory forest understory during leaf-out. Agric For Meteorol 132(1-2):28-43. https://doi.org/10.1016/j.agrformet. 2005.06.008

Grobelak A, Placek A, Grosser A, Singh BR, Almås ÅR, Napora A, Kacprzak M (2017) Effects of single sewage sludge application on soil phytoremediation. J Clean Prod 155:189-197. https://doi.org/ 10.1016/j.jclepro.2016.10.005

Guo C, Ma L, Yuan S, Wang R (2017) Morphological, physiological and anatomical traits of plant functional types in temperate grasslands along a large-scale aridity gradient in northeastern China. Sci Rep 7: 40900. https://doi.org/10.1038/srep40900

Howarth RW (1989) Determining the ecological effects of oil pollution in marine ecosystems. In: Levin SA, Kelly JR, Harwell MA, Kimball KD (eds) Ecotoxicology: problems and approaches. Springer New York, New York, pp 69-97

Hussain I, Aleti G, Naidu R, Puschenreiter M, Mahmood Q, Rahman MM, Wang F, Shaheen S, Syed JH, Reichenauer TG (2018) Microbe and plant assisted-remediation of organic xenobiotics and its enhancement by genetically modified organisms and recombinant technology: a review. Sci Total Environ 628-629:1582-1599. https://doi.org/10.1016/j.scitotenv.2018.02.037

Ivanov YV, Kartashov AV, Ivanova AI, Savochkin YV, Kuznetsov VV (2016) Effects of zinc on Scots pine (Pinus sylvestris L.) seedlings grown in hydroculture. Plant Physiol Biochem 102:1-9. https://doi. org/10.1016/j.plaphy.2016.02.014

Jarcuska B (2009) Growth, survival, density, biomass partitioning and morphological adaptations of natural regeneration in Fagus sylvatica. A review. Dendrobiology 61:3-11

International Energy Agency (2016) Annual Statistical Supplement. IEA Oil Market Report. Available at: https://www.iea.org/ oilmarketreport/omrpublic/. Accessed 25 Sep 2018

Joshi PC, Swami A (2009) Air pollution induced changes in the photosynthetic pigments of selected plant species. J Environ Biol 30(2): 295-298

Kalaji HM, Račková L, Paganová V, Swoczyna T, Rusinowski S, Sitko K (2018) Can chlorophyll- a fluorescence parameters be used as bioindicators to distinguish between drought and salinity stress in Tilia cordata Mill? Environ Exp Bot 152:149-157. https://doi.org/10. 1016/j.envexpbot.2017.11.001

Kamath R, Rentz JA, Schnoor JL, Alvarez PJJ (2004) Chapter 16 Phytoremediation of hydrocarbon-contaminated soils: principles and applications. In: Vazquez-Duhalt R, Quintero Ramírez R (eds)
Petroleum biotechnology. Developments and perspectives, vol 151. Elsevier, Amsterdam, pp 447-478

Kashparova E, Levchuk S, Morozova V, Kashparov V (2018) A dose rate causes no fluctuating asymmetry indexes changes in silver birch (Betula pendula (L.) Roth.) leaves and Scots pine (Pinus sylvestris L.) needles in the Chernobyl Exclusion Zone. J Environ Radioact. https://doi.org/10.1016/j.jenvrad.2018.05.015

Khan N, Warith MA, Luk G (2007) A comparison of acute toxicity of biodiesel, biodiesel blends, and diesel on aquatic organisms. J Air Waste Manag Assoc 57(3):286-296

Klamerus-Iwan A, Błońska E, Lasota J, Kalandyk A, Waligórski P (2015) Influence of oil contamination on physical and biological properties of forest soil after chainsaw use. Water Air Soil Pollut 226(11):389. https://doi.org/10.1007/s11270-015-2649-2

Kozlov M, Niemelä P (2003) Drought is more stressful for northern populations of Scots pine than low summer temperatures. Silva Fenn 37(2):175-180. https://doi.org/10.14214/sf.499

Kozlov MV, Niemelä P (1999) Difference in needle length - a new and objective indicator of pollution impact on scots pine (Pinus sylvestris). Water Air Soil Pollut 116:365-370. https://doi.org/10. 1023/A:1005213917615

Kozlov MV, Niemelä P, Junttila J (2002) Needle fluctuating asymmetry is a sensitive indicator of pollution impact on Scots pine (Pinus sylvestris). Ecol Indic 1(4):271-277. https://doi.org/10.1016/ S1470-160X(02)00023-7

Kuznetsova T, Rosenvald K, Ostonen I, Helmisaari H-S, Mandre M, Lõhmus K (2010) Survival of black alder (Alnus glutinosa L.), silver birch (Betula pendula Roth.) and Scots pine (Pinus sylvestris L.) seedlings in a reclaimed oil shale mining area. Ecol Eng 36(4): 495-502. https://doi.org/10.1016/j.ecoleng.2009.11.019

Kyć S (1981). Adaptation in morphological and anatomical construction of leaves for different light intensity and their relationship with photosynthetic properties. Annals of Philosophy 29(3): 85-109

Lange CA, Weissflog L, Strasser RJ, Krüger GHJ, Pfennigsdorff A, Musil CF, van Staden J (2004) Phytotoxic effects of trichloroacetic acid on Scots pine and birch determined by chl a fluorescence and the JIPtest. S Afr J Bot 70(5):683-694. https://doi.org/10.1016/S02546299(15)30167-8

Láposi R, Veres S, Lakatos G, Oláh V, Fieldsend A, Mészáros I (2009) Responses of leaf traits of European beech (Fagus sylvatica L.) saplings to supplemental UV-B radiation and UV-B exclusion. Agric For Meteorol 149(5):745-755. https://doi.org/10.1016/j. agrformet.2008.10.023

Lawson T, Oxborough K, Morison JIL, Baker NR (2002) Responses of photosynthetic electron transport in stomatal guard cells and mesophyll cells in intact leaves to light, $\mathrm{CO} 2$, and humidity. Plant Physiol 128(1):52-62

Leewis M-C, Reynolds CM, Leigh MB (2013) Long-term effects of nutrient addition and phytoremediation on diesel and crude oil contaminated soils in subarctic Alaska. Cold Reg Sci Technol 96:129 137. https://doi.org/10.1016/j.coldregions.2013.08.011

Lichtenthaler HK, Babani F (2004) Light Adaptation and Senescence of the Photosynthetic Apparatus. Changes in Pigment Composition, Chlorophyll Fluorescence Parameters and Photosynthetic Activity. In: Papageorgiou GC, Govindjee (eds) Chlorophyll a Fluorescence. Advances in Photosynthesis and Respiration, vol 19. Springer, Dordrecht

Löf M, Bolte A, Welander NT (2005) Interacting effects of irradiance and water stress on dry weight and biomass partitioning in Fagus sylvatica seedlings. Scand J For Res 20(4):322-328. https://doi. org/10.1080/02827580500201593

Mackerer CR, Griffis LC, Grabowski JS, Reitman FA (2003) Petroleum mineral oil refining and evaluation of cancer hazard. Appl Occup Environ Hyg 18(11):890-901. https://doi.org/10.1080/ 10473220390237467 
Marenco RA, Antezana-Vera SA, Nascimento HCS (2009) Relationship between specific leaf area, leaf thickness, leaf water content and SPAD-502 readings in six Amazonian tree species. Photosynthetica 47(2):184-190. https://doi.org/10.1007/ s11099-009-0031-6

Merkl N, Schultze-Kraft R, Infante C (2005) Assessment of tropical grasses and legumes for phytoremediation of petroleumcontaminated soils. Water Air Soil Pollut 165(1-4):195-209. https://doi.org/10.1007/s11270-005-4979-y

Mleczek M, Goliński P, Waliszewska B, Mocek A, Gąsecka M, Zborowska M, Magdziak Z, Cichy WJ, Mazela B, Kozubik T, Mocek-Płóciniak A, Moliński W, Niedzielski P (2018) The importance of substrate compaction and chemical composition in the phytoextraction of elements by Pinus sylvestris L. J Environ Sci Health A Tox Hazard Subst Environ Eng, 53(11):1029-1038. https://doi.org/10.1080/10934529.2018.1471116

Muilu-Mäkelä R, Vuosku J, Läärä E, Saarinen M, Heiskanen J, Häggman H, Sarjala T (2015) Water availability influences morphology, mycorrhizal associations, PSII efficiency and polyamine metabolism at early growth phase of Scots pine seedlings. Plant Physiol Biochem 88:70-81. https://doi.org/10.1016/j.plaphy.2015.01.009

Nevalainen O, Hakala T, Suomalainen J, Mäkipää R, Peltoniemi M, Krooks A, Kaasalainen S (2014) Fast and nondestructive method for leaf level chlorophyll estimation using hyperspectral LiDAR. Agric For Meteorol 198-199:250-258. https://doi.org/10.1016/j. agrformet.2014.08.018

Pająk M, Halecki W, Gąsiorek M (2017) Accumulative response of Scots pine (Pinus sylvestris L.) and silver birch (Betula pendula Roth) to heavy metals enhanced by $\mathrm{Pb}-\mathrm{Zn}$ ore mining and processing plants: explicitly spatial considerations of ordinary kriging based on a GIS approach. Chemosphere 168:851-859. https://doi.org/10.1016/j. chemosphere.2016.10.125

Palmroth MRT, Pichtel J, Puhakka J (2002) Phytoremediation of subarctic soil contaminated with diesel fuel. Bioresour Technol 84(3):221228. https://doi.org/10.1016/S0960-8524(02)00055-X

Papageorgiou GC (ed) Govindjee (eds) (2004) Chlorophyll a Fluorescence. A Signature of Photosynthesis. Advances in Photosynthesis and Respiration, vol 19. Springer, Dordrecht.

Pena R, Simon J, Rennenberg H, Polle A (2013) Ectomycorrhiza affect architecture and nitrogen partitioning of beech (Fagus sylvatica L.) seedlings under shade and drought. Environ Exp Bot 87:207-217. https://doi.org/10.1016/j.envexpbot.2012.11.005

Percival GC, Keary IP, AL-Habsi S (2006) An assessment of the drought tolerance of Fraxinus genotypes for urban landscape plantings. Urban For Urban Green 5(1):17-27. https://doi.org/10.1016/j.ufug. 2006.03.002

Petrová Š, Rezek J, Soudek P, Vaněk T (2017) Preliminary study of phytoremediation of brownfield soil contaminated by PAHs. Sci Total Environ 599-600:572-580. https://doi.org/10.1016/j. scitotenv.2017.04.163

Pietrini F, Iori V, Bianconi D, Mughini G, Massacci A, Zacchini M (2015) Assessment of physiological and biochemical responses, metal tolerance and accumulation in two eucalypt hybrid clones for phytoremediation of cadmium-contaminated waters. $\mathrm{J}$ Environ Manag 162:221-231. https://doi.org/10.1016/j. jenvman.2015.07.053

Pietrzykowski M, Socha J (2011) An estimation of Scots pine (Pinus sylvestris L.) ecosystem productivity on reclaimed post-mining sites in Poland (central Europe) using of allometric equations. Ecol Eng 37(2):381-386. https://doi.org/10.1016/j.ecoleng.2010.10.006

Pietrzykowski M, Woś B, Haus N (2013) Scots pine needles macronutrient (N, P, K, CA, MG, and S) supply at different reclaimed mine soil substrates - as an indicator of the stability of developed forest ecosystems. Environ Monit Assess 185(9):7445-7457. https://doi.org/ 10.1007/s10661-013-3111-9
Placek A, Grobelak A, Kacprzak M (2016) Improving the phytoremediation of heavy metals contaminated soil by use of sewage sludge. Int J Phytoremediation 18(6):605-618. https://doi.org/ 10.1080/15226514.2015.1086308

Popek R, Przybysz A, Gawrońska H, Klamkowski K, Gawroński SW (2018) Impact of particulate matter accumulation on the photosynthetic apparatus of roadside woody plants growing in the urban conditions. Ecotoxicol Environ Saf 163:56-62. https://doi.org/10. 1016/j.ecoenv.2018.07.051

Pšidová E, Živčák M, Stojnić S, Orlović S, Gömöry D, Kučerová J, Ditmarová L', Střelcová K, Brestič M, Kalaji HM (2018) Altitude of origin influences the responses of PSII photochemistry to heat waves in European beech (Fagus sylvatica L.). Environ Exp Bot 152:97-106. https://doi.org/10.1016/j.envexpbot.2017.12.001

Ribeiro de Souza SC, Adrián López de Andrade S, Anjos de Souza L, Schiavinato MA (2012) Lead tolerance and phytoremediation potential of Brazilian leguminous tree species at the seedling stage. $\mathrm{J}$ Environ Manag 110:299-307. https://doi.org/10.1016/j.jenvman. 2012.06.015

Sagerup K, Nahrgang J, Frantzen M, Larsen L-H, Geraudie P (2016) Biological effects of marine diesel oil exposure in red king crab (Paralithodes camtschaticus) assessed through a water and foodborne exposure experiment. Mar Environ Res 119:126-135. https://doi.org/10.1016/j.marenvres.2016.05.027

Sakugawa H, Cape JN (2007) Harmful effects of atmospheric nitrous acid on the physiological status of Scots pine trees. Environ Pollut 147(3):532-534. https://doi.org/10.1016/j.envpol.2007.02.012

Salmela MJ, Cavers S, Cottrell JE, Iason GR, Ennos RA (2011) Seasonal patterns of photochemical capacity and spring phenology reveal genetic differentiation among native Scots pine (Pinus sylvestris L.) populations in Scotland. For Ecol Manag 262(6):1020-1029. https://doi.org/10.1016/j.foreco.2011.05.037

Sarijeva G, Knapp M, Lichtenthaler HK (2007) Differences in photosynthetic activity, chlorophyll and carotenoid levels, and in chlorophyll fluorescence parameters in green sun and shade leaves of Ginkgo and Fagus. J Plant Physiol 164(7):950-955. https://doi.org/10.1016/ j.jplph.2006.09.002

Schaberg PG, DeHayes DH, Hawley GJ, Nijensohn SE (2008) Anthropogenic alterations of genetic diversity within tree populations: implications for forest ecosystem resilience. For Ecol Manag 256(5):855-862. https://doi.org/10.1016/j.foreco.2008.06.038

Seelig H-D, Wolter A, Schröder F-G (2015) Leaf thickness and turgor pressure in bean during plant desiccation. Sci Hortic 184:55-62. https://doi.org/10.1016/j.scienta.2014.12.025

Selonen S, Setälä H (2015) Soil processes and tree growth at shooting ranges in a boreal forest reflect contamination history and leadinduced changes in soil food webs. Sci Total Environ 518-519: 320-327. https://doi.org/10.1016/j.scitotenv.2015.03.018

Shirdam R, Zand A, Bidhendi G, Mehrdadi N (2008) Phytoremediation of hydrocarbon-contaminated soils with emphasis on the effect of petroleum hydrocarbons on the growth of plant species. Phytoprotection 89(1):21-29. https://doi.org/10.7202/000379ar

Sikorski Ł, Piotrowicz-Cieślak AI, Adomas B (2013) Phytotoxicity of sodium chloride towards common duckweed (Lemna minor L.) and yellow lupin (Lupinus luteus L.). Arch Environ Prot 39(2): 117-128. https://doi.org/10.2478/aep-2013-0018

Singer MM, Smalheer DL, Tjeerdema RS, Martin M (1990) Toxicity of an oil dispersant to the early life stages of four California marine species. Environ Toxicol Chem 9(11):1387-1395. https://doi.org/ 10.1002/etc.5620091108

Singh P, DeMarini DM, Dick CAJ, Tabor DG, Ryan JV, Linak WP, Kobayashi T, Gilmour MI (2004) Sample characterization of automobile and forklift diesel exhaust particles and comparative pulmonary toxicity in mice. Environ Health Perspect 112(8):820-825

Sousa CP, Pinto JJO, Martinazzo EG, Perboni AT, Farias ME, Bacarin MA (2014) Chlorophyll a fluorescence in rice plants exposed of 
herbicides of group imidazolinone. Planta Daninha 32(1):141-150. https://doi.org/10.1590/S0100-83582014000100016

Stefanowicz AM, Stanek M, Woch MW (2016) High concentrations of heavy metals in beech forest understory plants growing on waste heaps left by $\mathrm{Zn}-\mathrm{Pb}$ ore mining. J Geochem Explor 169:157-162. https://doi.org/10.1016/j.gexplo.2016.07.026

Sterling A, Melgarejo LM (2018) Leaf gas exchange and chlorophyll a fluorescence in Hevea brasiliensis in response to Pseudocercospora ulei infection. Physiol Mol Plant Pathol. https://doi.org/10.1016/j. pmpp.2018.07.006

Tamada IS, Montagnolli RN, Lopes PRM, Bidoia ED (2012) Toxicological evaluation of vegetable oils and biodiesel in soil during the biodegradation process, Braz J Microbiol. 43(4):1576-1581. https://doi.org/10.1590/S1517-838220120004000042

Tran TH, Mayzlish Gati E, Eshel A, Winters G (2018) Germination, physiological and biochemical responses of acacia seedlings (Acacia raddiana and Acacia tortilis) to petroleum contaminated soils. Environ Pollut 234:642-655. https://doi.org/10.1016/j. envpol.2017.11.067

Villacís J, Casanoves F, Hang S, Keesstra S, Armas C (2016) Selection of forest species for the rehabilitation of disturbed soils in oil fields in the Ecuadorian Amazon. Sci Total Environ 566-567:761-770. https://doi.org/10.1016/j.scitotenv.2016.05.102
Wang J, Liu X, Zhang X, Liang X, Zhang W (2011) Growth response and phytoremediation ability of reed for diesel contaminant. Procedia Environ Sci 8:68-74. https://doi.org/10.1016/j.proenv.2011.10.013

Xi Y, Song Y, Johnson DM, Li M, Liu H, Huang Y (2018) Se enhanced phytoremediation of diesel in soil by Trifolium repens. Ecotoxicol Environ Saf 154:137-144. https://doi.org/10.1016/j.ecoenv.2018. 01.061

Xiong P-p, He C-q, OH K, Chen X, Liang X, Liu X, Cheng X, Wu C-1, Shi Z-c (2018) Medicago sativa L. enhances the phytoextraction of cadmium and zinc by Ricinus communis L. on contaminated land in situ. Ecol Eng 116:61-66. https://doi.org/10.1016/j.ecoleng.2018. 02.004

Xie W, Li R, Li X, Liu P, Yang H, Wu T, Zhang Y (2018) Different responses to soil petroleum contamination in monocultured and mixed plant systems. Ecotoxicol Environ Saf 161:763-768. https://doi.org/10.1016/j.ecoenv.2018.06.053

Yilmaz DD (2007) Effects of salinity on growth and nickel accumulation capacity of Lemna gibba (Lemnaceae). J Hazard Mater 147(1-2): 74-77. https://doi.org/10.1016/j.jhazmat.2006.12.047

Zvereva EL, Kozlov MV, Niemelä P, Haukioja E, (1997) Delayed induced resistance and increase in leaf fluctuating asymmetry as responses of Salix borealis to insect herbivory. Oecologia 1093):368373 